\title{
Functions of Interneurons in Mouse Cerebellum
}

\author{
Neal H. Barmack and Vadim Yakhnitsa \\ Neurological Sciences Institute, Oregon Health \& Science University, Beaverton, Oregon 97006
}

The output signal of Purkinje cells is conveyed by the modulated discharge of simple spikes (SSs) often ascribed to mossy fiber-granule cell-parallel fiber inputs to Purkinje cell dendrites. Although generally accepted, this view lacks experimental support. We can address this view by controlling afferent signals that reach the cerebellum over climbing and mossy fiber pathways. Vestibular primary afferents constitute the largest mossy fiber projection to the uvula-nodulus. The discharge of vestibular primary afferent mossy fibers increases during ipsilateral roll tilt. The discharge of SSs decreases during ipsilateral roll tilt. Climbing fiber discharge [complex spikes (CSs)] increases during ipsilateral roll tilt. These observations suggest that the modulation of SSs during vestibular stimulation cannot be attributed directly to vestibular mossy fiber afferents. Rather we suggest that interneurons driven by vestibular climbing fibers may determine SS modulation. We recorded from cerebellar interneurons (granule, unipolar brush, Golgi, stellate, basket, and Lugaro cells) and Purkinje cells in the uvula-nodulus of anesthetized mice during vestibular stimulation. We identified all neuronal types by juxtacellular labeling with neurobiotin. Granule, unipolar brush, stellate, and basket cells discharge in phase with ipsilateral roll tilt and in phase with CSs. Golgi cells discharge out of phase with ipsilateral roll tilt and out of phase with CSs. The phases of stellate and basket cell discharge suggests that their activity could account for the antiphasic behavior of CSs and SSs. Because Golgi cells discharge in phase with SSs, Golgi cell activity cannot account for SS modulation. The sagittal array of Golgi cell axon terminals suggests that they contribute to the organization of discrete parasagittal vestibular zones.

Key words: mossy fiber; climbing fiber; inferior olive; nodulus; uvula; Golgi cell; stellate cell; granule cell; unipolar brush cell

\section{Introduction}

Purkinje cell discharge is influenced by climbing and mossy fiber afferents. Climbing fibers originate from the contralateral inferior olive and directly evoke low-frequency multipeaked "complex spikes" (CSs) [0.2-8.0 impulses (imp)/s]. Mossy fibers originate from vestibular primary afferents and multiple brainstem nuclei. They synapse, often bilaterally, on granule cells whose axons ascend to the molecular layer where they bifurcate and traverse the dendritic tree of Purkinje cells as parallel fibers. The main output signal of Purkinje cells is the modulated discharge of simple spikes (SSs) (20-60 imp/s) (Brand et al., 1976; Mugnaini, 1983; Harvey and Napper, 1991; Pichitpornchai et al., 1994). Whereas the modulation of CSs can be directly attributed to the action of climbing fibers, the modulation of SSs is less well understood, although often attributed to mossy fiber discharge (Granit and Phillips, 1956; Thach, 1970; Ebner and Bloedel, 1981; Armstrong and Edgley, 1988; Nagao, 1989; Lisberger et al., 1994).

Modulatory influences on SSs are not restricted to mossy fiber afferents. Several interneurons synapse on granule cells and/or Purkinje cells and may contribute to the modulation of SSs. Unipolar brush cells (UBCs) amplify vestibular primary afferent mossy fiber projections through synaptic feedforward excitation

Received Aug. 28, 2007; revised Dec. 14, 2007; accepted Dec. 17, 2007.

This work was supported by National Institute for Deafness and Communicative Disorders Grant DC006668 and National Eye Institute Grant EY018561. We thank Ms. Mary Westcott-Hodson for her expert histological assistance. Correspondence should be addressed to Dr. Neal H. Barmack, Neurological Sciences Institute, Oregon Health \& Science University, 505 Northwest 185th Avenue, Beaverton, 0R 97006. E-mail: barmackn@ohsu.edu. DOI:10.1523/JNEUROSCI.3942-07.2008

Copyright $\odot 2008$ Society for Neuroscience $\quad$ 0270-6474/08/281140-13\$15.00/0 onto granule cells (Diño et al., 2000; Nunzi et al., 2001). Basket cell inhibitory axon terminals encapsulate Purkinje cell somata (Andersen et al., 1964; Eccles et al., 1965; Fox et al., 1967). Stellate cell inhibitory axon terminals synapse directly on Purkinje cell smooth dendrites (Eccles et al., 1965; Fox et al., 1967). Golgi cell inhibitory axon terminals contribute to the classic glomerular synapse on granule cells shared by excitatory mossy fiber terminals (Cajal, 1911; Eccles et al., 1966; Hámori and Szentágothai, 1966; Fox et al., 1967). Golgi cells also inhibit UBCs (Dugué et al., 2005).

Several "systems level" requirements must be satisfied to understand how cerebellar cortical circuitry modulates Purkinje cell discharge. First, the topography of cerebellar afferents must be characterized so that effective stimuli can be used to drive cerebellar activity. Second, parametric control of the stimuli used to evoke mossy and climbing fiber activity must be established. Without such control, it is difficult to make inferences about functional circuitry. Third, independent control of mossy or climbing fiber pathways should be demonstrated. Such control would enable clear differentiation of their independent contributions. Fourth, anatomical identification of recorded interneurons is necessary to infer cell function. Investigation of the circuitry of the vestibulo-cerebellum satisfies these four requirements.

Vestibular primary afferent mossy fibers originate from each of the five ipsilateral vestibular endorgans and project to the ipsilateral nodulus and ventral uvula (Carpenter et al., 1972; Alley et al., 1975; Korte, 1979; Kevetter and Perachio, 1986; Gerrits et al., 1989; Barmack et al., 1993a; Purcell and Perachio, 2001; Maklad and Fritzsch, 2003) (see Fig. 1A). Vestibular primary afferents also project to the parasolitary nucleus (Barmack and Yakhnitsa, 


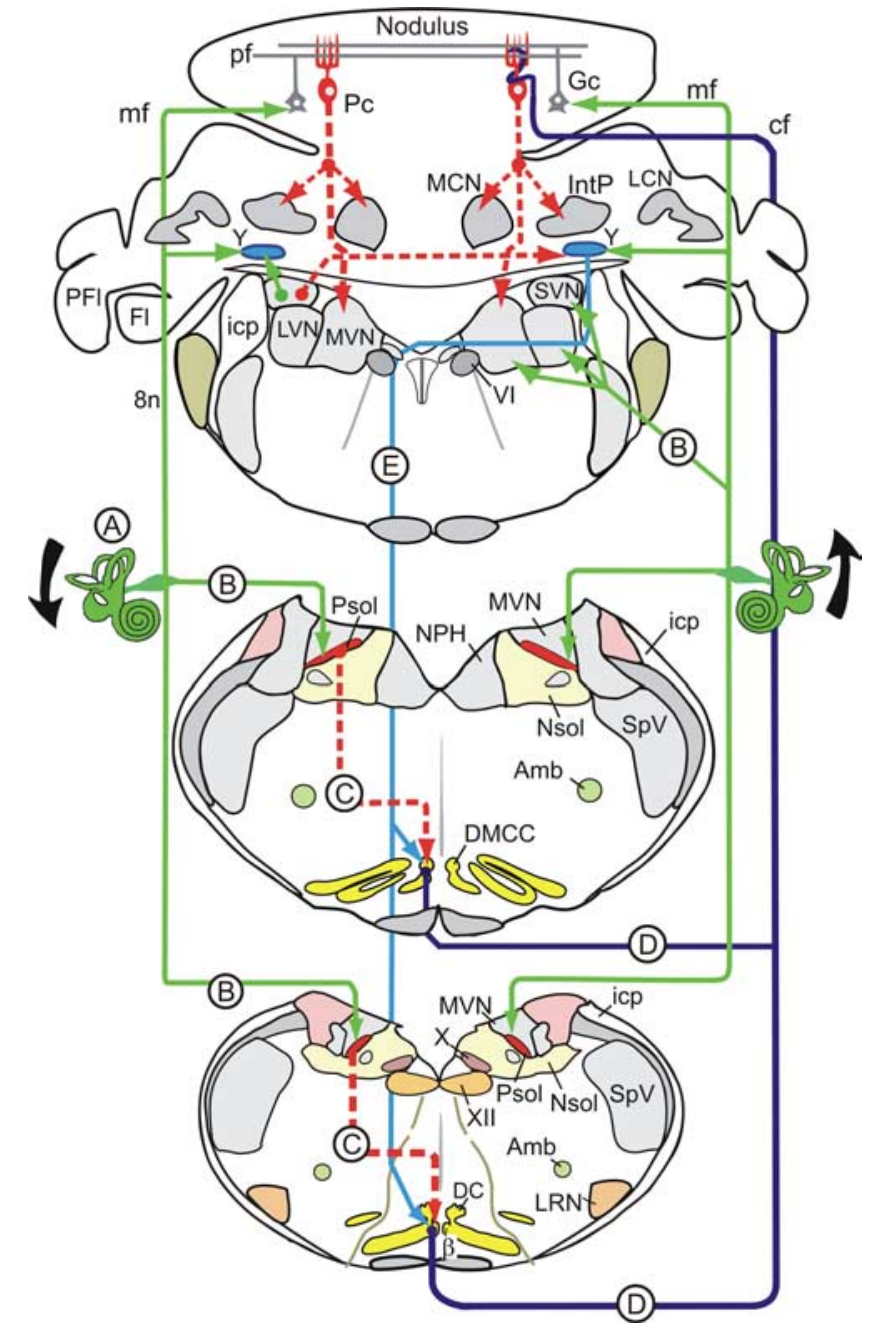

Figure 1. Vestibular-cerebellar circuitry. Solid lines indicate excitatory pathways. Dashed lines indicate inhibitory pathways. $A$, Roll tilt onto the left side increases vestibular primary afferent discharge. $\boldsymbol{B}$, Vestibular primary afferents project to ipsilateral parasolitary nucleus (Psol), Y-group (Y), and granule cell layer of nodulus. C, Psol projects to ipsilateral $\beta$-nucleus and DMCC. $\boldsymbol{D}$, Climbing fibers from the left $\beta$-nucleus and DMCC project to contralateral (right) nodulus. $E$, Y-group projects to contralateral dorsal cap (DC), $\beta$-nucleus, and DMCC. Amb, Nucleus ambiguus; cf, climbing fiber; DVN, descending vestibular nucleus; LVN, lateral vestibular nucleus; MVN medial vestibular nucleus; SVN, superior vestibular nucleus; $\mathrm{Fl}$, flocculus; Gc, granule cell; icp, inferior cerebellar peduncle; IntP, interpositus nucleus; LCN, lateral cerebellar nucleus; MCN, medial cerebellar nucleus; LRN, lateral reticular nucleus; Nsol, nucleus solitarius; PFI, paraflocculus; Pc, Purkinje cell; pf, parallel fiber; Psol, parasolitary nucleus; SpV, spinal trigeminal nucleus; $\mathrm{VI}$, abducens nucleus; $\mathrm{X}$, dorsal motor nucleus of the vagus; $\mathrm{XII}$, hypoglossal nerve; 8 n, vestibular nerve.

2000) (Fig. $1 B$ ). The parasolitary nucleus, in turn, conveys a purely GABAergic signal to the ipsilateral $\beta$-nucleus and dorsomedial cell column (DMCC) of the ipsilateral inferior olive (see Fig. 1C). Vestibular secondary afferent mossy fibers also project bilaterally to the nodulus and ventral uvula from the descending, medial and superior vestibular nuclei (Brodal and Torvik, 1957; Kotchabhakdi and Walberg, 1978; Yamamoto, 1979; Brodal and Brodal, 1985; Thunnissen et al., 1989; Epema et al., 1990). Climbing fibers from the $\beta$-nucleus and DMCC project to the contralateral uvula-nodulus (Barmack et al., 1993b; Barmack and Shojaku, 1995; Barmack and Yakhnitsa, 2003) (Fig. 1D).

During roll tilt about the longitudinal axis, both vestibular primary afferent mossy fibers and vestibular climbing fibers are modulated. Roll tilt onto the left side increases the discharge of ipsilateral (left) vestibular primary afferent mossy fibers. Roll tilt onto the left side also increases the discharge of climbing fibers that originate from the contralateral (right) inferior olive and synapse on Purkinje cells in the ipsilateral (left) uvula-nodulus. The ipsilateral (left) primary afferent mossy fiber signal reflects increased depolarization of hair cells in the left labyrinth. The increased climbing fiber discharge reflects decreased excitability of the contralateral (right) primary afferents and the consequent decreased GABAergic input mediated by the right parasolitary nucleus onto the right DMCC and $\beta$-nucleus. Thus, the primary vestibular afferent signal and the climbing fiber signal originate independently from opposite labyrinths. Despite their separate origins, both vestibular primary afferent mossy fibers and vestibular climbing fibers discharge in phase with ipsilateral roll tilt.

Paradoxically, SSs discharge in phase with contralateral roll tilt (Barmack and Shojaku, 1995; Fushiki and Barmack, 1997; Barmack and Yakhnitsa, 2003; Yakhnitsa and Barmack, 2006). Interneurons likely play a role in the phase reversal of SSs with respect to vestibular primary afferent mossy fiber signal. Here we examine the cellular basis of this paradox. We investigate how sinusoidal roll tilt modulates the activity of cerebellar interneurons identified by juxtacellular labeling (Pinault, 1996; Simpson et al., 2005; Holtzman et al., 2006). We measure the vestibularly evoked depth and phase of modulation of Purkinje cell and interneuronal discharge with the aim of discovering how interneurons contribute to the modulation of SSs.

\section{Materials and Methods}

Anesthesia and surgery. Seventy-four C57BL/6J mice (The Jackson Laboratory, Bar Harbor, ME) (weight, 16.0-29.0 g) were anesthetized with intraperitoneal injections of ketamine $(60-70 \mathrm{mg} / \mathrm{kg})$ and xylazine (3 $\mathrm{mg} / \mathrm{kg}$ ). Anesthetic depth was evaluated using paw withdrawal and corneal reflexes. Body temperature was maintained at $37^{\circ} \mathrm{C}$ by a servocontrolled heating pad. Mice received supplemental doses of ketamine alone every 20-25 min.

Dental acrylic, anchored to the calvarium by four small stainless-steel screws $(0-80 \times 1 / 8)$, affixed an inverted stainless steel screw (4-40) between the lambda and bregma sutures. The inverted screw mated with a metal bar that maintained the head rigidly in the center of a three-axis vestibular rate table.

The uvula-nodulus was approached by reflecting the muscles overlying the occipital bone. An opening $(3 \times 2 \mathrm{~mm})$ was made in occipital bone over folia 7 and 8 . A slit $(1 \mathrm{~mm})$ was made in the dura mater. The opening was covered with warm mineral oil. Anesthesia induction and surgical procedures together lasted $40-60 \mathrm{~min}$. All animal procedures were approved in advance by the Institutional animal care and use committee of Oregon Health \& Science University.

Microelectrode recording. Microelectrodes were drawn from $1.5 \mathrm{~mm}$ capillaries on a two stage puller. They were filled with $2-3 \%$ neurobiotin in $0.5 \mathrm{M} \mathrm{NaCl}$ and had $10-20 \mathrm{M} \Omega$ tip impedances. Microelectrodes were advanced through folium 8 toward folia 9 and 10 with a digitally controlled hydraulic microdrive. The maximum penetration distance from the dorsal surface of folium 8 to the ventral surface of folium 10 was 2.2 $\mathrm{mm}$.

Histological verification of recording sites by juxtacellular labeling with neurobiotin. Neurons were labeled juxtacellularly by ejecting neurobiotin from the micropipette using a stimulus train of positive current pulses (1-5 nA, $300 \mathrm{~ms}, 50 \%$ duty cycle) for 1-3 min (Pinault, 1996; Simpson et al., 2005; Holtzman et al., 2006). A "loose patch" was achieved by increasing current amplitude until the discharge frequency of the recorded neuron was modulated. After juxtacellular stimulation was completed, the micropipette was usually withdrawn to prevent damage to the recorded neuron. Approximately $80 \%$ of the cells stimulated juxtacellularly for $>1.5 \mathrm{~min}$ were later identified histologically. Experiments lasted $\sim 2.5 \mathrm{~h}$. A typical collection of labeled neurons included 6-10 Purkinje cells and 2-4 interneurons. 

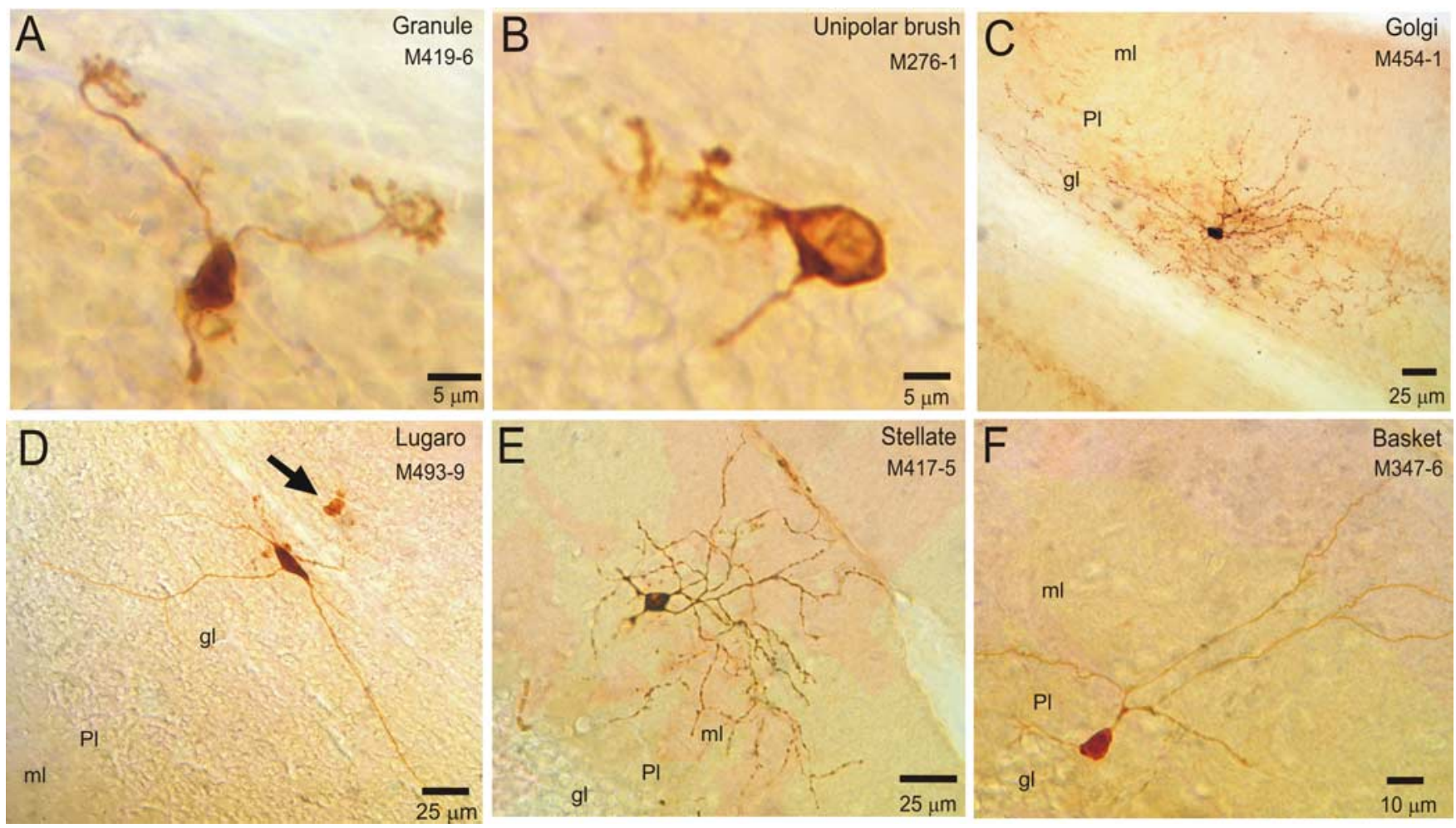

Figure 2. Six interneurons identified by juxtacellular stimulation. Interneurons filled with neurobiotin by juxtacellular stimulation are shown. $\boldsymbol{A}$, Granule cell. $\boldsymbol{B}$, Unipolar brush cell. $\boldsymbol{C}$, Golgi cell. $\boldsymbol{D}$, Lugaro cell. The arrow indicates four granule cells that were colabeled after juxtacellular staining of the Lugaro cell. $\boldsymbol{E}$, Stellate cell. $\boldsymbol{F}$, Basket cell. Note that the scale bar differs for each cell type. $\mathrm{gl}$, Granule cell layer; $\mathrm{ml}$, molecular layer; PI, Purkinje cell layer.

Approximately $45 \mathrm{~min}$ after labeling the last cell in an experiment, the mouse was deeply anesthetized and perfused transcardially with $20 \mathrm{ml}$ of $0.9 \% \mathrm{NaCl}$, followed by $100 \mathrm{ml}$ of $4 \%$ paraformaldehyde and $0.1 \%$ picric acid in $0.1 \mathrm{M}$ PBS, pH 7.4. The brain was removed and fixed overnight at $4^{\circ} \mathrm{C}$. Some brains were serially sectioned at $50 \mu \mathrm{m}$ on a vibratome. Others were cryoprotected, frozen and cut serially on a cryostat at $45 \mu \mathrm{m}$. Freefloating sections were processed according to a biotin/streptavidin-HRP protocol.

Photomicroscopy. Labeled neurons were photographed with a digital camera. Images were obtained at three different levels of focus for each neuron. They were combined with a digital image fusion program (Image Pro Plus; Media Cybernetics, Bethesda, MD) to obtain an extended depth of field.

Vestibular stimulation. The mouse was mounted on a three-axis vestibular rate table in the prone position. The rate table oscillated the mouse sinusoidally about a vertical axis (yaw), longitudinal axis (roll), and interaural axis (pitch, $\pm 10^{\circ}, 0.005-0.800 \mathrm{~Hz}$ ). All recorded neurons were tested with a stimulus frequency of $\sim 0.2 \mathrm{~Hz}$.

Data analysis. Action potentials were analyzed using Spike 2 software (Cambridge Electronic Design, Cambridge, UK) and displayed in peristimulus histograms, constructed by storing interspike intervals (ISIs) in one of 180 bins. Bin width varied with the reciprocal of stimulus frequency: bin width, $1 /(f)(180)$.

Spike frequency for each bin was computed from the reciprocal of the mean ISI as follows: mean rate $=1 /\left(\sum\right.$ ISIs in bin $) /($ bin spike count $)$.

This method is preferable to simply adding spike occurrences to bins while discarding information concerning interspike intervals, particularly for low numbers of spike occurrences (Barmack and Yakhnitsa, 2003). Peristimulus histograms included $10-50$ cycles of vestibular stimulation $(0.1-0.2 \mathrm{~Hz})$ and were fitted with a cosine function by a least squares method. The phase of responses re: head position was derived from the fitted cosine function: $Y(t)=M \cos (2 \pi f t+\varphi)+B$, where $M$ is the depth of modulation, $B$ is the average discharge rate, $\varphi$ is the phase relative to head position, and $f$ is the stimulus frequency.

Interspike interval histograms (ISIHs) were computed for each cere- bellar cell type using a bin width of $5 \mathrm{~ms}$ and a sampling interval of 500 $\mathrm{ms}$. For Purkinje cell SSs, we used the $5 \mathrm{~ms}$ bin width and $500 \mathrm{~ms}$ sampling interval. For CSs we used a $50 \mathrm{~ms}$ bin width and a $5 \mathrm{~s}$ sampling interval. The purpose of comparing median and mean ISIs was to ascertain whether a relatively skewed responses were predictive of cell type (Vos et al., 1999; Simpson et al., 2005; Holtzman et al., 2006).

Neurons were classified as "responsive" if the second harmonic was $<50 \%$ of the fundamental and if they had a signal-to-noise ratio $>1.5$. The second criterion was sensitive to all harmonics and was particularly applicable to neurons with saturated or "cutoff" responses (Schor et al., 1984). Data are presented as mean \pm SD. Polar plots are constructed for each population of identified neurons. The amplitude of the vector in these plots indicates mean $M$. The vector angle indicates the mean $\varphi$ with respect to head position during ipsilateral roll tilt.

\section{Results}

\section{Juxtacellularly identified cerebellar interneurons}

Using the technique of juxtacellular labeling we identified two excitatory interneurons (granule cells, UBCs) and four inhibitory interneurons (Lugaro cells, Golgi cells, stellate cells, and basket cells) (Fig. 2A-F). Each cell type has a distinctive morphology and histological location that render its identity certain. Granule cells were identified by their location, their small cell bodies $(<6$ $\mu \mathrm{m}$ ), and their sparse dendrites that have claw-like endings (Fig. $2 A)$. UBCs have chalice-like cell bodies $(8-10 \mu \mathrm{m})$ attached to a single, stubby, branched dendrite. They are located within the granule cell layer (Fig. 2B). Golgi cells have large cell bodies $(10-20 \mu \mathrm{m})$ with extensive branching of their varicose axon terminals within the granule cell layer (Fig. 2C). Most often, Golgi cell dendrites extend into the molecular layer. Lugaro cells, like Golgi cells, have large cell bodies $(10-20 \mu \mathrm{m})$. However, unlike Golgi cells, Lugaro cell axons are smooth and straight, ending in the granule cell layer. Like the dendrites of Golgi cells, Lugaro cell 

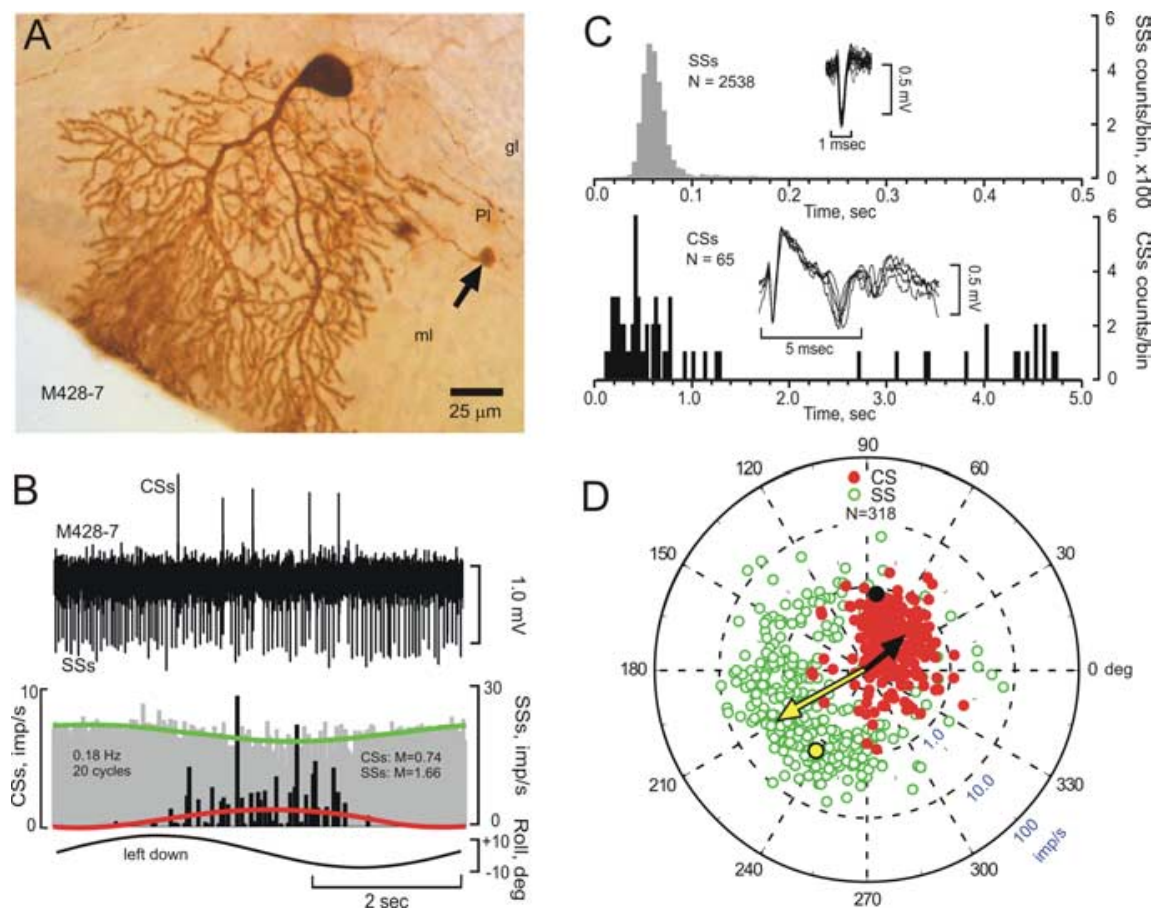

Figure 3. Purkinje cell CSs respond in phase with ipsilateral sinusoidal roll tilt. A, Juxtacellularly labeled Purkinje cell M428-7 was located $800 \mu \mathrm{m}$ to the right of the midline in folia 10 . The arrow indicates a molecular layer interneuron that was colabeled after juxtacellular staining of the Purkinje cell. B, CSs and SSs were modulated by sinusoidal roll tilt. Peristimulus histogram shows that the discharge of CSs (black bars) increased and SSs (gray bars) decreased during ipsilateral roll tilt. The histograms were fitted with cosine functions (CSs, red line; SSs, green line). C, An ISIH for M428-7 shows a broad distribution of intervals for both CSs and SSs. Note the different time scales for CSs and SSS. The CS is illustrated with five and the SS is illustrated with 25 superimposed traces. D, A polar plot of the 269/318 responsive Purkinje cells illustrates antiphasic discharge of CSs (red circles) and SSs (open green circles). The population vector for CSs (black arrow) had $M=0.25 \mathrm{imp} / \mathrm{s}$ and $\varphi=43^{\circ}$. For the population vector for SSs, $M=1.3 \mathrm{imp} / \mathrm{s}$ and $\varphi=209^{\circ}$. Responses for M428-7 are represented by the filled black (CS) and yellow (SS) circles. For abbreviations, see Figure 2 .

dendrites usually penetrate the molecular layer (Fig. $2 D$ ). Stellate cells have small cell bodies $(8-12 \mu \mathrm{m})$ and multiple sparsely branched ("stellate") dendrites, confined to the molecular layer (Fig. 2E). Basket cells have laterally projecting axon terminals that envelop adjacent Purkinje cell somata and few, relatively unbranched apical dendrites that ascend into the molecular layer (Fig. $2 F$ ).

Juxtacellular stimulation sometimes labeled more than one neuron. Granule cells were the most often secondarily labeled interneurons (see Figs. 2D, 3A, 7A). The distance of secondarily labeled granule cells from the juxtacellularly targeted neuron suggests that granule cell labeling occurred as a consequence of retrograde uptake of neurobiotin by parallel fiber terminals. This interpretation accounts for secondarily labeled granule cells found across a divide of white matter in separate granule cell layers from juxtacellularly stimulated neurons (Fig. 2D).

Below, we physiologically characterize five of the six interneurons illustrated in Figure 2. We exclude Lugaro cells from our analysis because we have conclusively identified only two.

\section{Purkinje cell responses}

The modulated discharge of CSs and SSs during roll tilt, previously observed in Purkinje cells in the rabbit and mouse uvulanodulus, was confirmed (Barmack and Yakhnitsa, 2003; Yakhnitsa and Barmack, 2006). We recorded from 318 Purkinje cells. One hundred and seventy-eight of these Purkinje cells were reported previously (Yakhnitsa and Barmack, 2006). The activity of 269 of 318 Purkinje cells was modulated by vestibular stimula- tion. Purkinje cells were identified by the classic waveforms of CSs and SSs and by juxtacellular labeling (Fig. $3 A-D$ ).

A polar plot of responsive Purkinje cells illustrates that the modulation of CSs (red circles) and SSs (open green circles) was antiphasic (Fig. 3D). The population vector for CSs (black arrow) had an $M$ of 0.25 $\mathrm{imp} / \mathrm{s}$ and a $\varphi$ of $43^{\circ}$. For SSs, $M=1.3$ $\mathrm{imp} / \mathrm{s}$ and $\varphi=209^{\circ}$.

Responsive cells were distributed in folia 8-10. The discharge of CSs in 249/269 Purkinje cells increased during ipsilateral roll tilt. The discharge of $20 \mathrm{CS}$ s increased during contralateral roll tilt. Of the 20 contralaterally responding CSs, 14 were localized to folia 8 and 9 a.

The average discharges of CSs and SSs were $0.2 \pm 0.3 \mathrm{imp} / \mathrm{s}$ and $20.1 \pm 10 \mathrm{imp} / \mathrm{s}$ respectively $(n=318)$. The mean and median ISIs were $2.64 \pm 0.86 \mathrm{~s}$ and $1.79 \mathrm{~s}(n=$ 40) for CSs and $0.06 \pm 0.03 \mathrm{~s}$ and $0.06 \mathrm{~s}$ $(n=40)$ for SSs. The ISIHs for CSs had a tail of responses with longer ISIs, as indicated by a comparison of the mean and median ISIs.

Previously, we showed that optimal planes of vestibular stimulation were represented in $400-\mu \mathrm{m}$-wide sagittal zones in the uvula-nodulus. Optimal planes for CSs and SSs consistent with stimulation of the ipsilateral posterior and contralateral anterior semicircular canals were localized to a medial zone. Optimal planes consistent with stimulation in the plane of the ipsilateral anterior and contralateral posterior semicircular canals were represented in a lateral zone (Yakhnitsa and Barmack, 2006). We characterized as many Purkinje cells and interneurons as rapidly as possible, by restricting vestibular stimulation to roll tilt about the longitudinal axis, rather than define the "null" and "optimal" planes for each neuron. We confirmed that sinusoidal roll tilt about the longitudinal axis modulated responses of CSs and SSs in Purkinje cells with similar $M$ and $\varphi$ whether the cells were activated optimally by preferential stimulation about the axis for either the anterior or posterior semicircular canals. Although there was a slight reduction in $M$ for CSs and SSs during stimulation about the longitudinal axis, $\varphi$ remained constant. The vector differences were not significant ( $F$ tests, $p>0.5 ; n=20)(Z a r$, 1984).

\section{Mossy fiber terminals}

Although we did not include them among the distinctive neuronal cell types encountered in the cerebellar cortex, we successfully labeled four mossy fiber terminals within the granule cell layer (Fig. 4A). The anatomical identity of mossy fibers was established by their classic rosette terminals. The paucity of our sample does not reflect their density within the cerebellum. Mossy fibers comprise the largest afferent pathway to the cerebellum. There are $\sim 5.0$ mossy fibers per Purkinje cell and 0.1 climbing fibers per Purkinje cell, yielding an estimate of 50 times more mossy than climbing fibers (Ito, 1984). Rather, it reflects the difficulty in juxtacellularly labeling them without also labeling other cells 

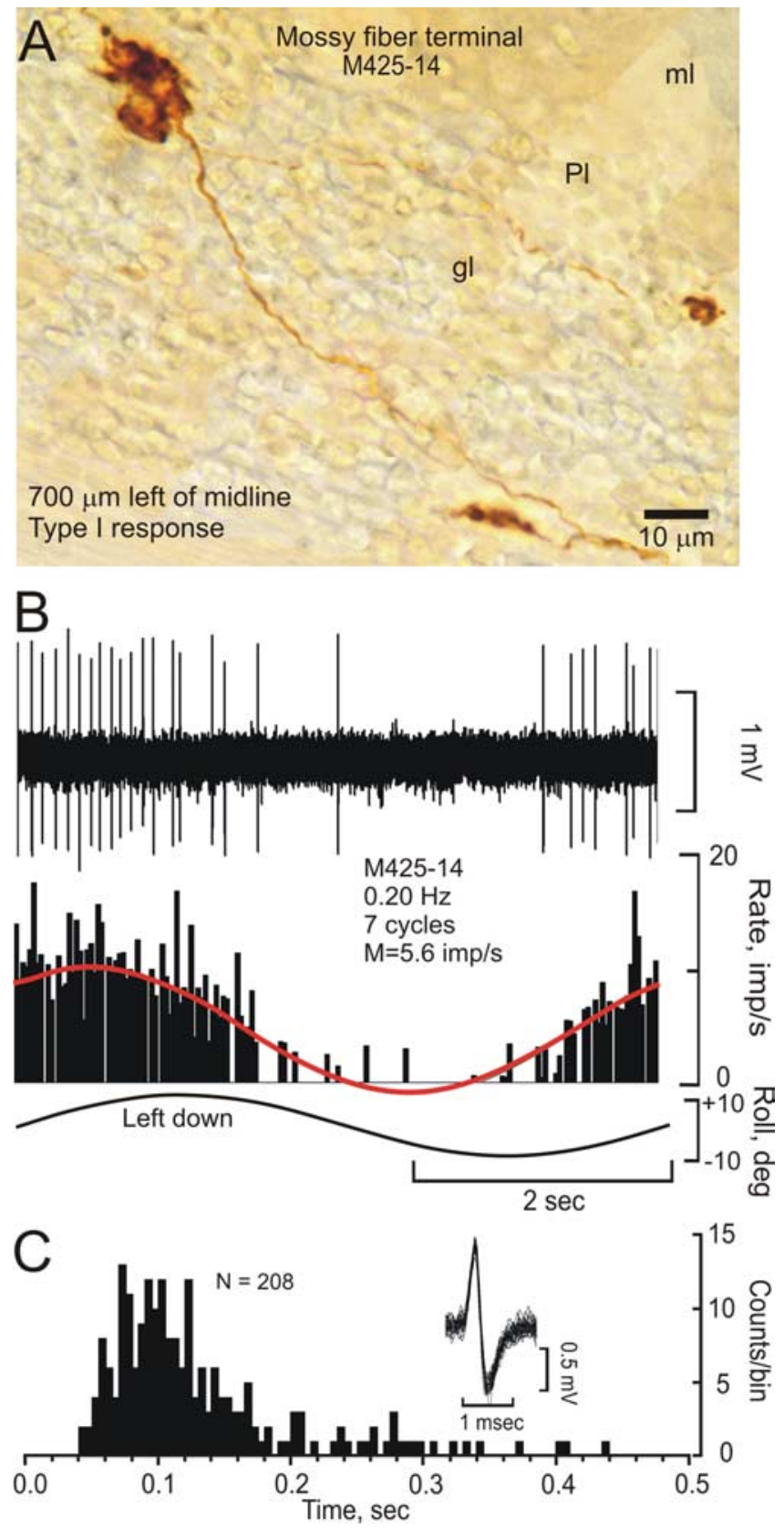

Figure 4. Mossy fiber terminal type I response. $A$, Juxtacellularly labeled mossy fiber terminal M425-14 was located $700 \mu \mathrm{m}$ to the left of the midline in folium $9 c$. B, It had a type I response. Its discharge increased during ipsilateral roll tilt. The peristimulus histogram (black bars) was fitted with a cosine function (red line). C, An ISIH shows a broad distribution of intervals. The action potential is illustrated with 25 superimposed traces. For abbreviations, see Figure 2.

within the granular layer with which their physiological responses could be confused.

The activity of two of four identified mossy fibers was modulated by vestibular stimulation. The discharge of one, localized $700 \mu \mathrm{m}$ to the left folium 9c (uvula), evinced a type I response by increasing its discharge during ipsilateral (left) roll tilt (type I) (Fig. $4 B$ ). The vestibularly evoked activity of mossy fibers was well modulated $(M=5.1 \mathrm{imp} / \mathrm{s}$ for the type I mossy fiber; $M=$ $10.1 \mathrm{imp} / \mathrm{s}$ for the type II mossy fiber). The action potential of mossy fibers was brief, lasting $<1 \mathrm{~ms}$ (Fig. $4 C$ ). The average discharge rate for the four juxtacellularly identified mossy fibers was
$7.1 \pm 4.4 \mathrm{imp} / \mathrm{s}$. The mean and median ISIs for mossy fiber terminal discharge were $0.14 \pm 0.08 \mathrm{~s}$ and $0.12 \mathrm{~s}(n=4)$, respectively.

\section{Granule cells}

We recorded from a total of 38 granule cells in folia $8-10$. The identity of granule cells was established by their small somata $(4-6 \mu \mathrm{m})$ and their sparse claw-like dendrites (Figs. $2 A, 5 A)$. It was difficult to isolate single granule cells unless we used electrodes with tip impedances $>15 \mathrm{M} \Omega$. The discharge of 28 of 38 granule cells was modulated by vestibular stimulation. Of these modulated granule cells 19 of 28 had type I responses.

In 12 of 28 vestibularly driven granule cells, the low-frequency modulation was preceded by a phase-locked high-frequency burst $(50-200 \mathrm{~Hz})$ (Fig. 5B,C). We define "bursts" as two or more successive action potentials with ISIs $>50$ times shorter than the average ISI during vestibular stimulation (a single burst is shown in Fig. 5B). Granule cell bursts did not occur during every cycle of vestibular stimulation. In the cell illustrated in Figure $5 B$, bursts appeared in 9 of 11 cycles. Lower discharge rates also occurred within each cycle. In 12 granule cells with both bursts and regular discharges, we measured $M$ and $\varphi$ for the combined responses and for each response separately. We fitted cosine functions to peristimulus histograms that included both the bursts and the "regular discharges" (Fig. 5B1, red cosine function and red vector). We examined bursts only (Fig. 5B2, green cosine function). Bursts had $M=0.6 \mathrm{imp} / \mathrm{s}$ and $\varphi=44^{\circ}$ (Fig. $5 B 2$, green vector). We excluded bursts and analyzed only the modulated lower rate of discharge (Fig. 5B3, blue cosine function). Under this condition, $M=0.7 \mathrm{imp} / \mathrm{s}$ and $\varphi=334^{\circ}$ (Fig. $5 B 3$, blue vector).

In 5 of 28 vestibularly driven granule cells, we observed only high-frequency bursts. In 11 of 28 vestibularly driven granule cells, we observed only low-frequency modulation (for example of a vestibularly modulated granule cell that lacked bursts, see Fig. $10 A, C)$.

The mean discharge of the 28 vestibularly responsive granule cells was $3.3 \pm 3.8 \mathrm{imp} / \mathrm{s}$. A polar plot for this population had a vector (red arrow) with $M=0.71$ and $\varphi=5^{\circ}$ (Fig. 5D). Vestibular modulation of granule cells was less than that of mossy fibers. The high-frequency bursting discharge of granule cells was reflected in the ISIH with two distinct peaks; one reflecting short ISIs, the other reflecting longer intervals (Fig. 5C, red arrowhead).

The discharge of granule cells was divided into regular (slow) and burst discharge. The mean and median ISIs for regular granule cell discharge were $0.21 \pm 0.18 \mathrm{~s}$ and $0.20 \mathrm{~s}(n=33)$. Granule cell bursts had mean and median ISIs of $0.05 \pm 0.07 \mathrm{~s}$ and $0.05 \mathrm{~s}$ $(n=17)$, respectively.

\section{Unipolar brush cells}

Unipolar brush cells (UBCs) are found in abundance in the granule cell layer, particularly in the uvula-nodulus (Mugnaini and Floris, 1994; Diño et al., 2000). We recorded from 31 UBCs, identified in the granule cell layer by their larger somata $(8-10$ $\mu \mathrm{m}$ ) and characteristic brush-like endings (Figs. 2B, 6A). The discharge of $27 / 31$ UBCs was modulated by sinusoidal roll tilt (Fig. 6 B). Ipsilateral roll tilt increased the discharge of 19 of 27 of the vestibularly modulated UBCs (type I). The population response of UBCs had a phase lead $\left(\varphi=32^{\circ}\right)$ with respect to ipsilateral roll tilt (Fig. 6D). The average discharge frequency of UBCs was $10.0 \pm 11.6 \mathrm{imp} / \mathrm{s}$. The average depth of modulation $(M=1.2 \mathrm{imp} / \mathrm{s})$ was greater than that of granule cells, but less 

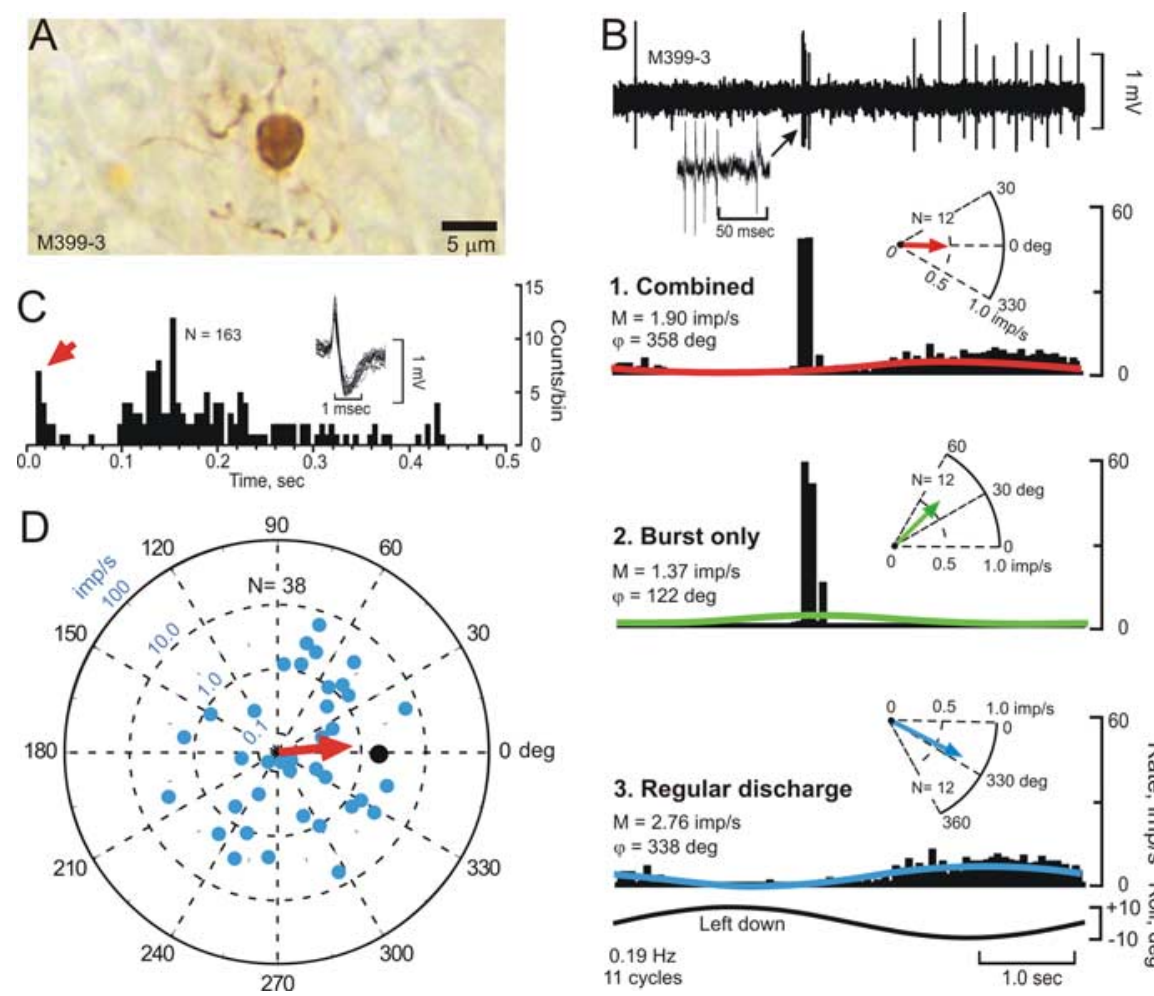

Figure 5. Granule cells respond to roll tilt with low rates and with bursts. $A$, Granule cell M399-3 was located $50 \mu \mathrm{m}$ to the right of the midline in folium 9 c. $\boldsymbol{B}$, Vestibularly modulated slow responses were interspersed in 9 of 11 stimulus cycles with highfrequency bursts. Three peristimulus histograms were plotted and included different combinations of bursts and regular discharge: bursts and regular discharge were fitted with a cosine function (red line; 1); bursts only were plotted (cosine function, green line; 2); and regular discharges, without bursts, were plotted (cosine function, blue line; 3 ). The vectors in $B 1-B 3$ indicate the average $M$ and $\varphi$ for each condition. C, An ISIH shows two discrete peaks of interspike intervals. The first (red arrowhead) corresponds to the high-frequency bursts. The second consists of more broadly distributed ISIs and corresponds to regular discharge. The action potential is illustrated with 25 superimposed traces. $\boldsymbol{D}$, A polar plot for the population of 28 vestibularly responsive granule cells yielded a vector (red arrow) with $M=0.7 \mathrm{imp} / \mathrm{s}$ and $\varphi=5^{\circ}$. The combined response of $M 399-3$ is indicated by the filled black circle.

than that of mossy fiber afferents. The mean and median ISIs of UBCs were $0.12 \pm 0.10 \mathrm{~s}$ and $0.11(n=31)$, respectively (Fig. $6 C)$.

\section{Golgi cells}

Golgi cells contribute inhibitory axon terminals to cerebellar glomeruli, the principal sites of mossy fiber termination on granule cells. Golgi cells also inhibit UBCs (Dugué et al., 2005).

Extensive axonal branching enables Golgi cells to modulate the activity of thousands of granule cells. Light and electron microscopic evidence suggests that climbing fibers synapse on Golgi cells (Hámori and Szentágothai, 1966, 1980; Desclin, 1976; Sugihara et al., 1999). This could allow climbing fiber signals to influence the activity of large numbers of granule cells and UBCs, and, in turn, induce a modulated SS output that is out of phase with mossy fiber-granule cell signaling.

Golgi cells identified by their relatively large somata (10-20 $\mu \mathrm{m}$ ), extensive axonal branching within the granule cell layer and projection of dendrites toward the molecular layer (Figs. $2 C$ and $7 A$ ). We recorded from 24 Golgi cells. They had large action potentials with low average discharge rates $(2.7 \pm 2.1 \mathrm{imp} / \mathrm{s})$. The discharge of 18 of these cells was modulated by sinusoidal roll tilt. The discharge of 15/18 of these modulated cells increased during contralateral roll tilt (Fig. $7 B$ ). A polar plot for the population of 18 vestibularly responsive Golgi cells yielded a vector (black arrow) with $M=0.7 \mathrm{imp} / \mathrm{s}$ and $\varphi=180^{\circ}$ (Fig. $7 D$ ). The ISIs of Golgi cells, like those of CSs had a distinct low-frequency tail. The mean and median ISIs were $0.23 \pm 0.22 \mathrm{~s}$ and $0.16 \mathrm{~s}(n=23)$, respectively (Fig. 7C).

The extent of dendritic and axonal terminal distribution of Golgi cells is difficult to discern from inspection of photomicrographs (Figs. 2C, 7A). Lower power photomicrographs fail to capture the detail of the small diameter, varicose Golgi cell processes. Higher-power photomicrographs fail to capture their spatial extent. Therefore we traced the patterns of axonal branching in nine of the better-labeled Golgi cells to gain insight into possible function (Fig. 8). These tracings highlight the most impressive aspect of Golgi cell organization. Their axon terminals have a parasagittal organization. The mean sagittal extent of Golgi cell axons was $650 \pm 179 \mu \mathrm{m}$. The mean mediolateral extent was $180 \pm 40$ $\mu \mathrm{m}(n=9)$.

Because the tissue sections were cut sagittally, we could follow the sagittal trajectories of axons and dendrites in the granule cell and molecular layers. Mediolateral trajectories could be followed with less precision, because measurements were restricted to increments of $45-50 \mu \mathrm{m}$, the thickness of the tissue sections. Peripheral processes may be incompletely labeled juxtacellularly. However, the possibility of more extensive branching than we have measured would not alter the conclusion that Golgi cell axon terminals are sagittally organized.

The dendrites of Golgi cells have a more varied morphology than do the axon terminals. In most Golgi cells, two to four dendrites emerge as thicker processes from a single locus on the soma. More peripherally, the dendrites narrow and are more varicose in appearance. In fact, peripherally, we could not distinguish Golgi cell dendrites from axons. Consequently, it was not possible to obtain a quantitative estimate of dendritic organization. For comparison, we measured the asymmetry of the relatively planar dendritic trees of the 6 Purkinje cells. The maximal linear extent of the Purkinje cell dendritic tree was $190 \pm 35 \mu \mathrm{m}$ in the sagittal plane and $120 \pm 23$ $\mu \mathrm{m}$ mediolaterally $(n=6)$.

The uvula-nodulus is organized into at least three physiologically defined parasagittal zones (Yakhnitsa and Barmack, 2006). Both the CSs and SSs in these zones respond optimally to vestibular stimulation about either the axis of the posterior or anterior semicircular canals. The width of these parasagittal vestibular zones within the mouse uvula-nodulus is $\sim 400 \mu \mathrm{m}$. Golgi cell dendrites and axon terminals could fit within single parasagittal zone. Golgi cells could provide one of the mechanisms by which similar CS and SS receptive fields are imposed on the discharge of granule cells, even if those granule cells received overlapping or conflicting mossy fiber primary afferent signals.

\section{Stellate cells}

Stellate cells are the only neurons localized exclusively to the molecular layer. We recorded from 47 stellate cells during sinu- 
soidal roll tilt (Figs. 2E, 9A). They had dendritic fields of $\sim 200 \mu \mathrm{m}$ and somata of 7-10 $\mu \mathrm{m}$ in diameter.

Stellate cells are abundant. We counted stellate cells in the molecular layer of the mouse nodulus in Nissl-stained, $45-\mu \mathrm{m}$ thick sagittal sections. In each of five sections, we counted stellate cells in a molecular layer that included five Purkinje cells. In five separate samples, we obtained a mean of $22.9 \pm 1.5$ stellate cells/Purkinje cell.

The discharge of 37 of 47 stellate cells was modulated by vestibular stimulation. Of the driven stellate cells, 31 of 37 increased their discharge during ipsilateral roll tilt (Fig. 9B,D). The discharge of the other six stellate cells increased during contralateral roll tilt. Four of these contralaterally responding stellate cells were localized to folium $9 \mathrm{a}$, a folium with less uniform sagittal organization. A polar plot for the population of 37 vestibularly responsive stellate cells yielded a vector (black arrow) with $M=2.0 \mathrm{imp} / \mathrm{s}$ and $\varphi=11^{\circ}$.

The average discharge rate of stellate cells was $10.0 \pm 10.9 \mathrm{imp} / \mathrm{s}$. The mean and median ISIs for stellate cells were $0.13 \pm$ $0.10 \mathrm{~s}$ and $0.14 \mathrm{~s}(n=47)$, respectively (Fig. 9C).

The phase and depth of modulation of the stellate cell population suggest that they could provide an inhibitory input to Purkinje cells, in phase with the climbing fibers and vestibular primary afferent mossy fibers, but out of phase with SSs (Fig. 9D). Stellate cells could account for the antiphasic discharge of CSs and SSs.

\section{Basket cells}

Basket cell somata are found in the lower molecular layer just above Purkinje cells. Their identification depends on the presence of characteristic terminals that envelop Purkinje cell somata and on their relatively long, smooth and sparsely branching dendrites (Figs. $2 F, 10 A$ ).

Figure 10 shows a labeled granule cell (M372-3) as well as a labeled basket cell (M372-4). The discharge of the granule cell was continuously modulated and had no bursts. Its discharge increased during ipsilateral roll tilt (Fig. $10 A, C, D$ ). We were unable to maintain juxtacellular stimulation of the granule cell for more than $1 \mathrm{~min}$. Rather than withdraw the microelectrode, we continued the track. We quickly encountered and labeled the basket cell. Its discharge was modulated by ipsilateral roll tilt (Fig. $10 A, B, D)$.

In total, we identified five basket cells, four of whose discharge was modulated by ipsilateral roll tilt. A polar plot for the population of $4 / 5$ vestibularly responsive basket cells yielded a vector with $M=0.8 \mathrm{imp} / \mathrm{s}$ and $\varphi=1^{\circ}$ (Fig. $10 D$ ). The average discharge
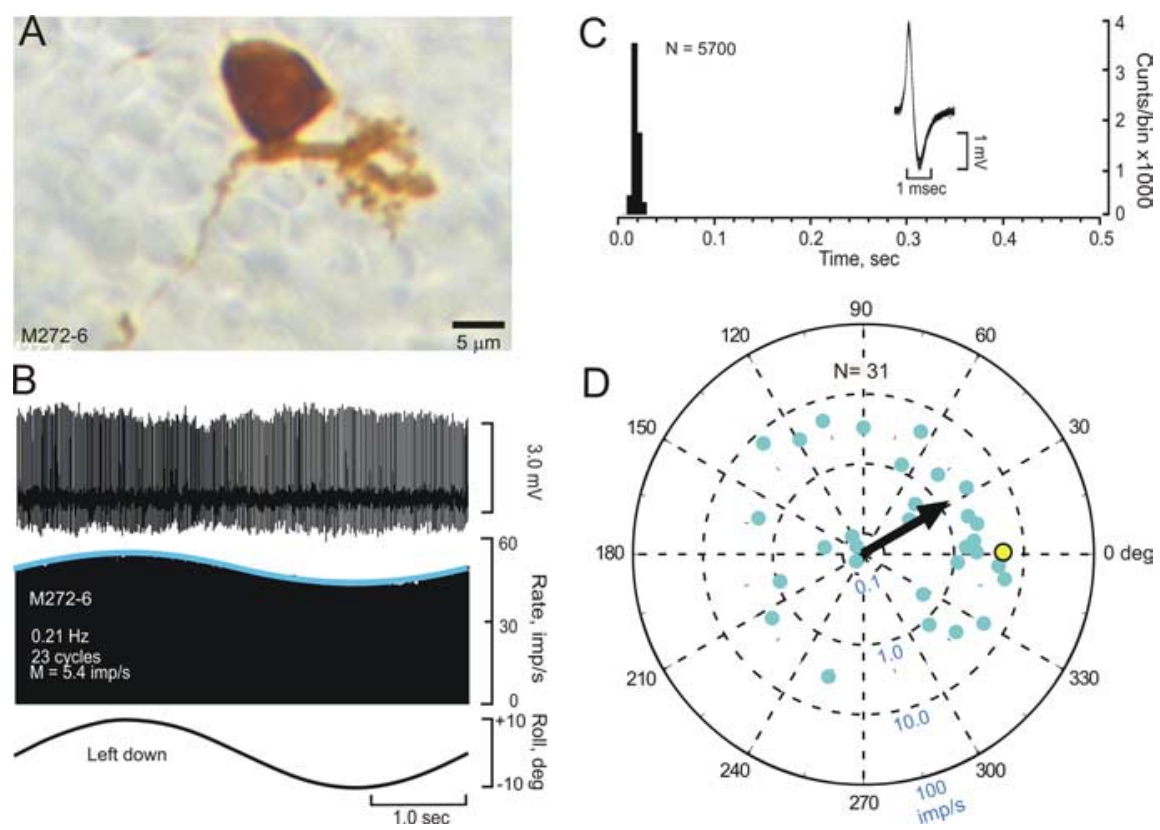

Figure 6. UBCs respond to roll tilt. $A$, Juxtacellularly labeled UBC M272-6 was located $350 \mu \mathrm{m}$ to the left of the midline in folium 10. $\boldsymbol{B}$, The activity of M272-6 increased during ipsilateral roll tilt. The peristimulus histogram was fitted with a cosine function (blue line). C, An ISIH shows a narrow peak of interspike intervals. The action potential is illustrated with 25 superimposed traces. $\boldsymbol{D}$, A polar plot for the population of 27 vestibularly responsive UBCs yielded a vector (black arrow) with $M=5.4$ $\mathrm{imp} / \mathrm{s}$ and $\varphi=32^{\circ}$. The response of M272-6 is indicated by the filled yellow circle.
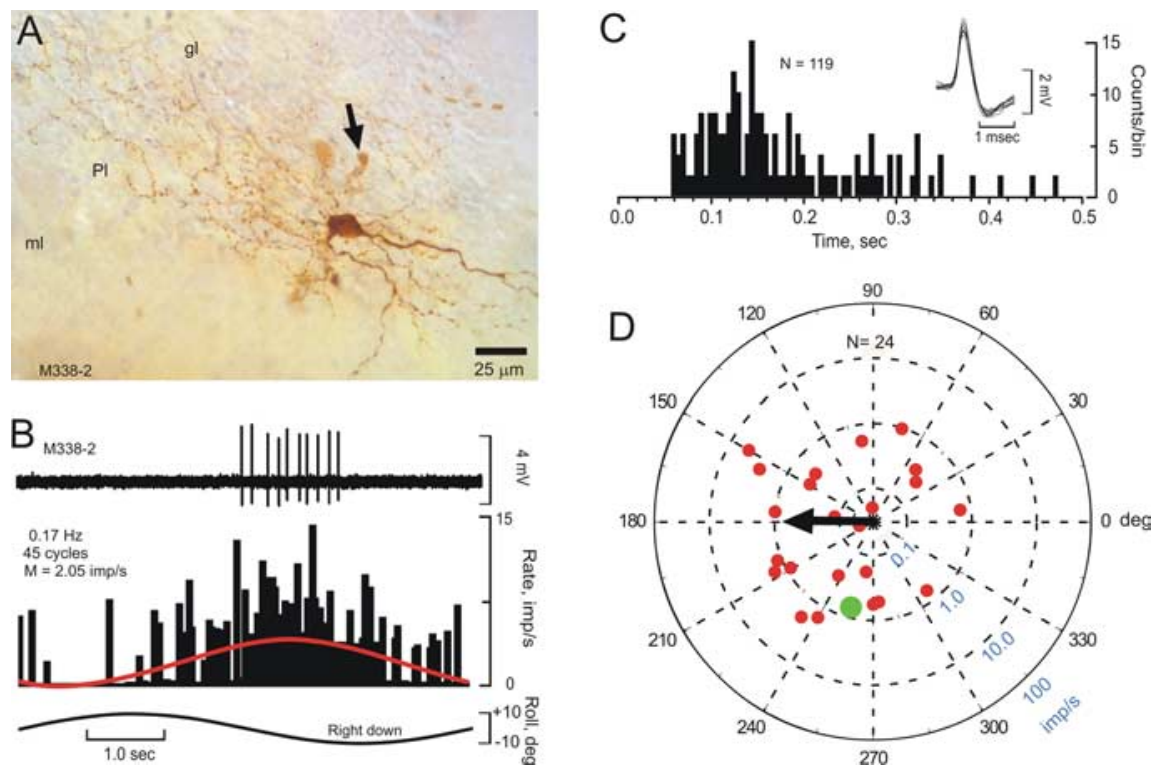

Figure 7. Golgi cell activity increases during contralateral roll tilt. $A$, Juxtacellularly labeled Golgi cell M338-2 was located $300 \mu \mathrm{m}$ to the left of the midline in folium 10. The arrow indicates a granule cell that was colabeled by juxtacellular staining of the Golgi cell. $B$, Golgi cell M338-2 discharged in phase with contralateral roll tilt velocity. Its peristimulus histogram was fitted with a cosine function (red line). C,An ISIH for M338-2 shows a broad distribution of intervals. The action potential is illustrated with 10 superimposed traces. D, A polar plot for the population of 18 vestibularly responsive Golgi cells yields a vector (black arrow) with $M=0.7 \mathrm{imp} / \mathrm{s}$ and $\varphi=180^{\circ}$. The response of Golgi cell M338-2 is indicated by the filled green circle. For abbreviations, see Figure 2 .

rate of basket cells was $4.8 \pm 6.6 \mathrm{imp} / \mathrm{s}$. The mean and median ISIs of basket cells were $0.15 \pm 0.06 \mathrm{~s}$ and $0.11 \mathrm{~s}(n=5)$, respectively. Basket cells were similar to CSs and Golgi cells in having an extended tail of longer ISIs (Fig. 10B).

\section{Topography and polarity of interneuronal responses}

The population responses of two excitatory interneurons (granule cells and UBCs) and a major inhibitory interneuron, the stel- 


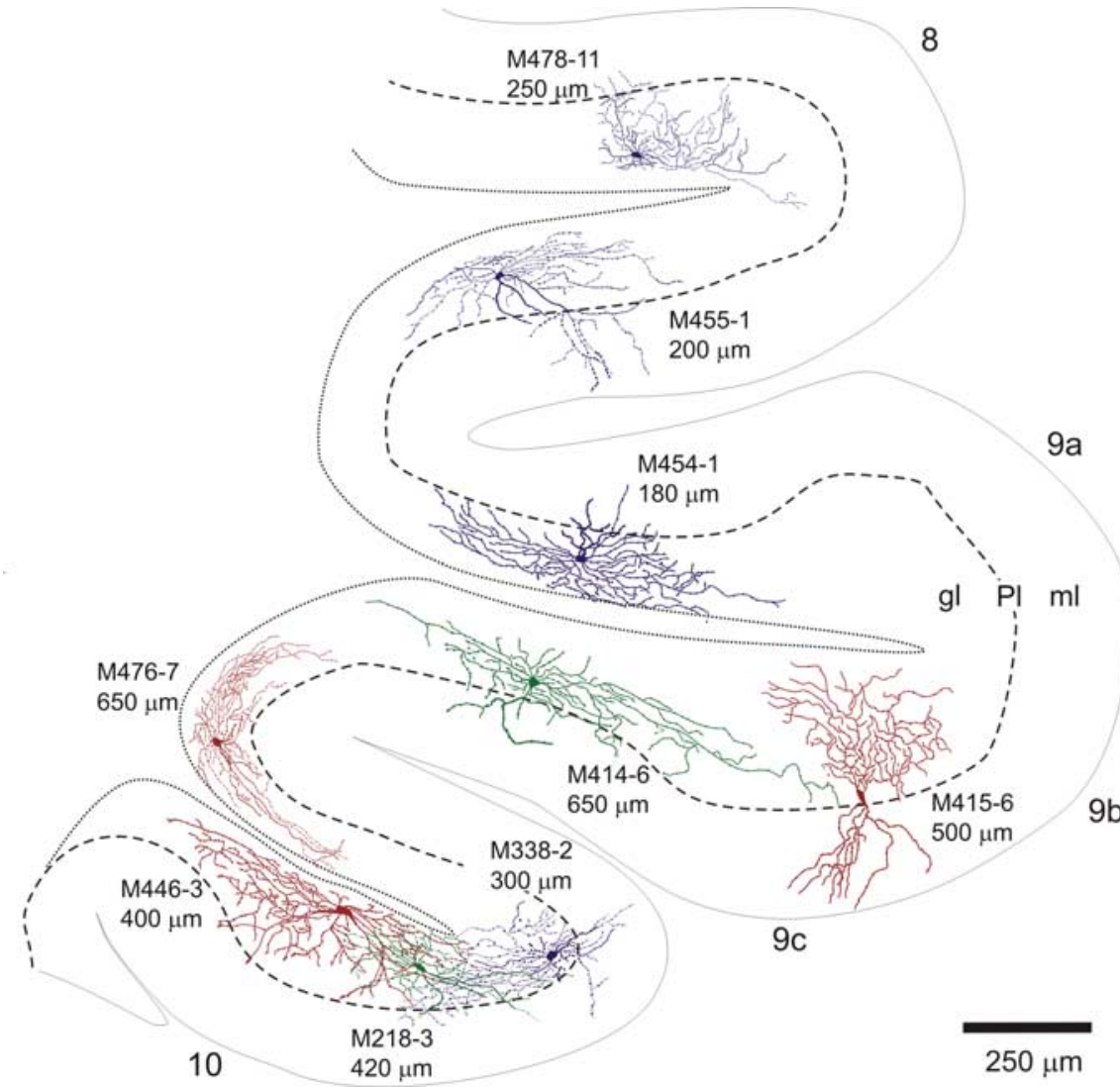

Figure 8. Parasagittal organization of Golgi cells. Nine juxtacellularly labeled Golgi cells are drawn in the sagittal plane through folia $8-10$. Each is characterized by profusely branching, fine, varicose axons within the granule cell layer. The distance of each cell from the midline is listed. Colors are used to help distinguish the processes of different Golgi cells. For abbreviations, see Figure 2.
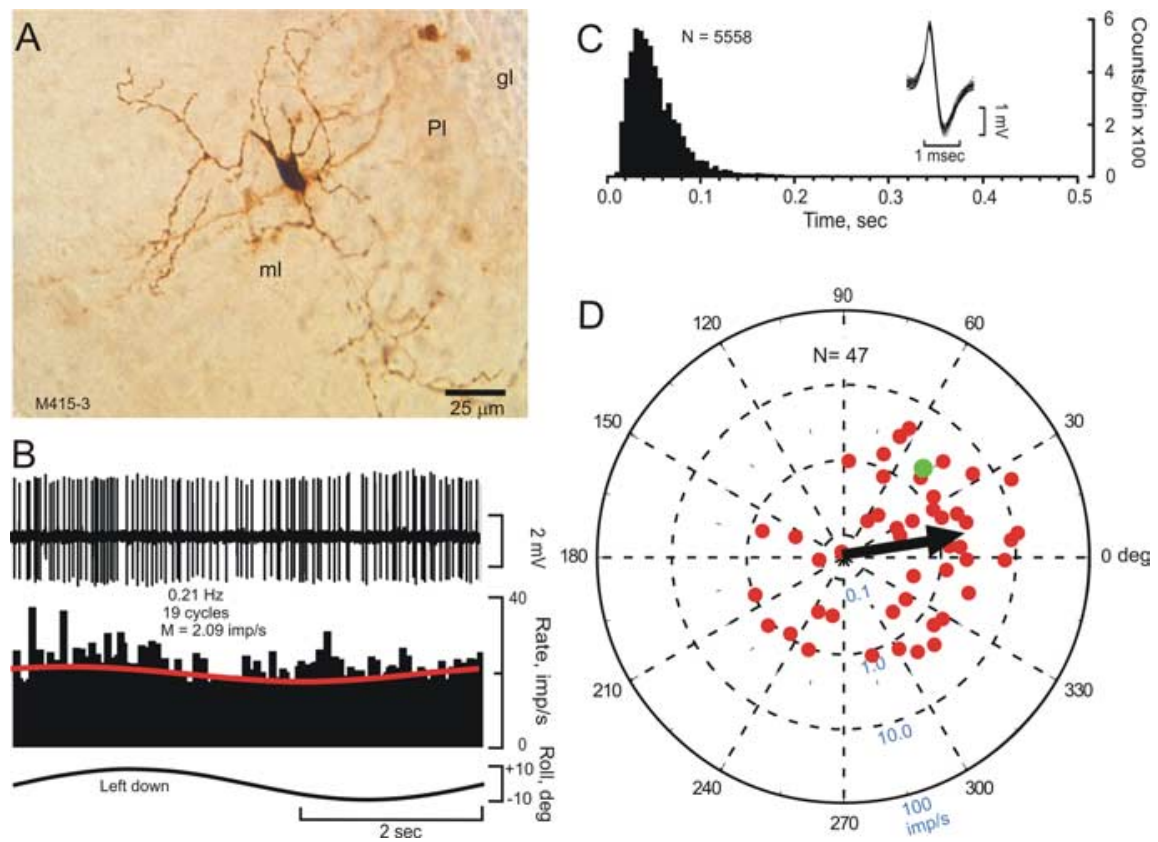

Figure 9. Stellate cells respond to ipsilateral roll tilt. $A$, Juxtacellularly labeled stellate cell M415-3 was located $250 \mu \mathrm{m}$ left of the midline in folium 9 c. B, The activity of M415-3 was modulated by ipsilateral roll tilt. The peristimulus histogram was fitted with a cosine function (red line). C, An ISIH shows a relatively broad peak of interspike intervals. The action potential is illustrated with 25 superimposed traces. $\boldsymbol{D}$, A polar plot for the population of 37 vestibularly responsive stellate cells yields a vector (black arrow) with $M=2.0 \mathrm{imp} / \mathrm{s}$ and $\varphi=11^{\circ}$. The response of $M 415-3$ is indicated by the filled green circle. For abbreviations, see Figure 2. late cell, have similar phases during sinusoidal roll tilt. The population responses of these interneurons were within $20^{\circ}$ of ipsilateral roll tilt. Granule cells and UBCs had both type I and type II responses, but with a clear preponderance of type I responses. The responses of Golgi cells differed from those of other interneurons. The population response of Golgi cells was in phase with contralateral roll tilt $\left(\varphi=180^{\circ}\right)$. This response indicates that Golgi cells discharge out of phase with both CSs $\left(\varphi=43^{\circ}\right)$, as well as granule cell-parallel fibers $\left(\varphi=5^{\circ}\right)$, but in phase with SSs $\left(\varphi=209^{\circ}\right)$.

Vestibularly evoked activity of granule cells, Golgi cells and stellate cells, but not UBCs was observed as frequently in folia 8 and $9 a$ as it was in folia $9 c$ and 10 , although most of vestibular primary and secondary afferent projections are concentrated in folia 9b,c and 10 (Fig. 11) (Brodal and Hoivik, 1964; Carleton and Carpenter, 1984; Barmack et al., 1993a). These data suggest that vestibular-related activity of granule, Golgi and stellate cells may be more dependent on climbing fiber than mossy fiber-granule cell-parallel fiber activity.

\section{Discussion}

Antiphasic behavior of CSs and SSs

Although the modulation of SSs is almost universally attributed to activation of mossy fiber pathways (Thach, 1970; Ebner and Bloedel, 1981; Armstrong and Edgley, 1988; Nagao, 1989; Kano et al., 1991; Lisberger et al., 1994) several experimental observations are inconsistent with this point of view. First, after the occurrence of a CS, a pause in SSs ensues whose duration exceeds any direct effect of the climbing fiber on Purkinje cell conductances (Granit and Phillips, 1956; Armstrong and Rawson, 1979; McDevitt et al., 1982; Barmack and Shojaku, 1995; Fushiki and Barmack, 1997; Kobayashi et al., 1998; Fukushima et al., 1999; Schiffmann et al., 1999; Blazquez et al., 2003; Schonewille et al., 2006; Winkelman and Frens, 2006). Second, electrical stimulation of the inferior olive evokes a pause in SSs. This pause persists even when the strength of olivary stimulation is adjusted so that it does not evoke a CS from the cell from which SSs are recorded (Bloedel and Roberts, 1971). Consequently, the CS-associated pause in SSs cannot be attributed to a membrane property of the Purkinje cell (Monsivais et al., 2005). More likely, it reflects the action of climbing fibers on one or more classes of cerebellar interneurons. The 

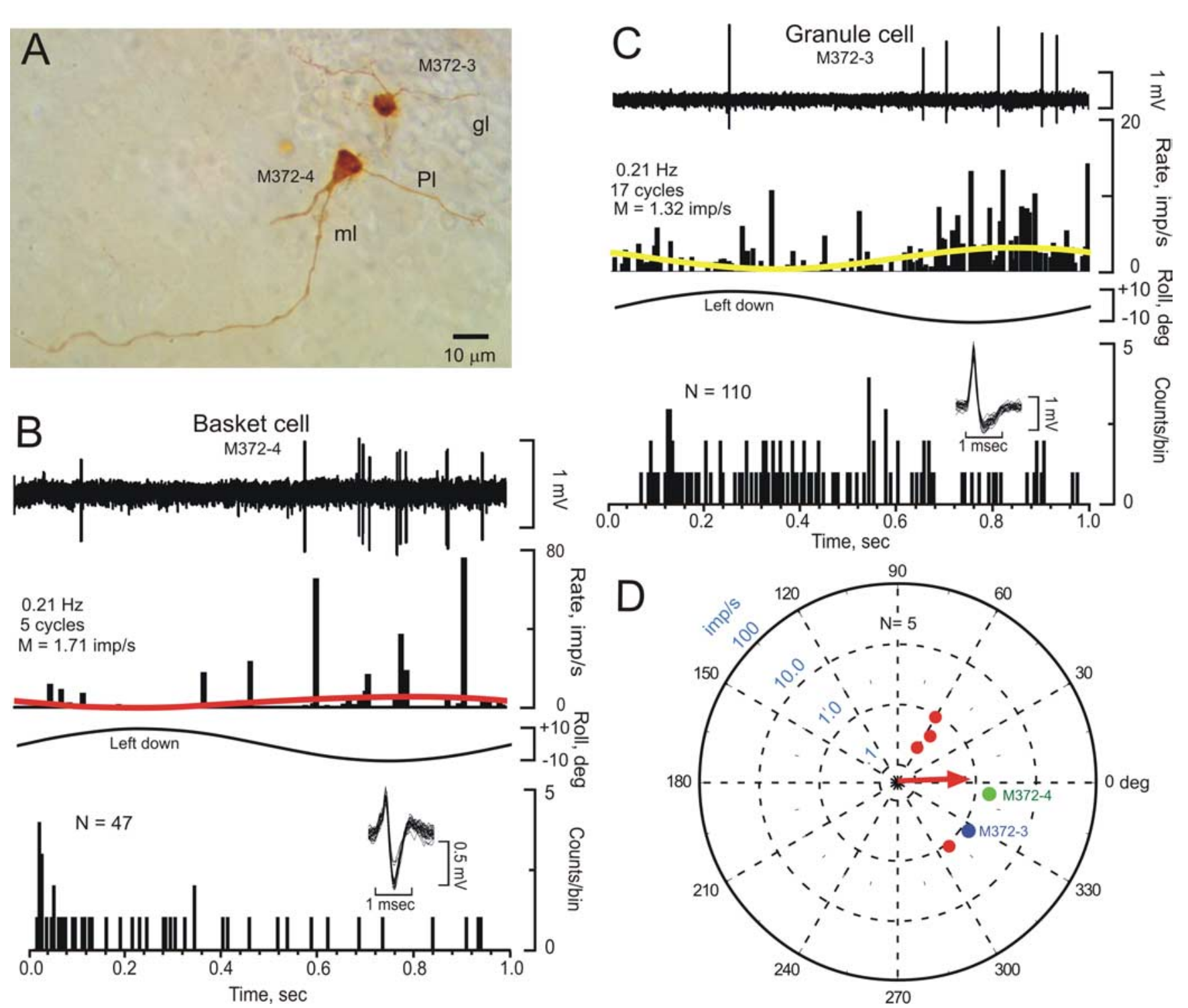

Figure 10. Basket cells respond to ipsilateral roll tilt. $\boldsymbol{A}$, Photomicrograph shows two separately labeled cells; a basket cell (M372-4) and a granule cell (M372-3) located in folium 10, 100 $\mu$ m to the right of the midline. Discharges of both cells were modulated by ipsilateral roll tilt. $B, C$, Both cells were fitted with a cosine function (basket cell-red line, granule cell-yellow line). The third trace for each cell is an ISIH. Each shows a relatively broad distribution of interspike intervals. Action potentials are illustrated with 25 superimposed traces. The granule cell lacked the bursts that characterized the discharge of other granule cells. $D$, A polar plot for the population of four of five vestibularly responsive basket cells yields a vector (red arrow) with $M=0.8$ imp/s and $\varphi=1^{\circ}$. The response of basket cell M372-4 is indicated by the filled green circle. The response of granule cell M372-3, not included in the computation of the basket cell vector, is indicated by the filled blue circle. For abbreviations, see Figure 2.

phases of vestibularly evoked stellate and basket cell discharge suggest that these inhibitory interneurons could induce climbing fiber-evoked pauses in SSs. Third, the activity of vestibular primary afferent mossy fibers is modulated $180^{\circ}$ out of phase with the discharge of SSs and therefore cannot account for the modulation of SSs (Barmack and Shojaku, 1995). Fourth, CS and SS modulation in nodular Purkinje cells occurs only during roll-pitch. Modulation does not occur during yaw, even though horizontal semicircular canal primary afferents project onto granule cells in the uvula-nodulus (Kevetter and Perachio, 1986; Barmack and Shojaku, 1995; Fushiki and Barmack, 1997; Purcell and Perachio, 2001; Newlands et al., 2002; Maklad and Fritzsch, 2003). This suggests that vestibular primary afferents not only have the wrong polarity, but that their synaptic influence is too weak to account for the observed modulation of SSs. Fifth, vestibularly modulated SSs persist in the uvula-nodulus even after all ipsilateral vestibular primary afferent mossy fiber signals have been eliminated by a unilateral labyrinthectomy (Barmack and Yakhnitsa, 2003). Sixth, a unilateral microlesion of the $\beta$-nucleus reduces CS and SS modulation in the contralateral uvula-nodulus even though vestibular primary and secondary mossy fiber afferents remain intact (Barmack and Yakhnitsa, 2003). These last two points suggest that modulation of primary vestibular mossy fiber afferents is neither necessary nor sufficient for the modulation of SSs.

Terminals from single mossy fibers lack topographic specificity. They are distributed in the granule cell layer both mediolaterally and rostrocaudally over several millimeters of cerebellar cortex, in multiple folia (Kevetter and Perachio, 1986; Wu et al., 1999; Purcell and Perachio, 2001; Newlands et al., 2002; Maklad and Fritzsch, 2003). Any remaining topographic precision conveyed by mossy fiber signals to the granule cell layer is further reduced mediolaterally by the projections of 

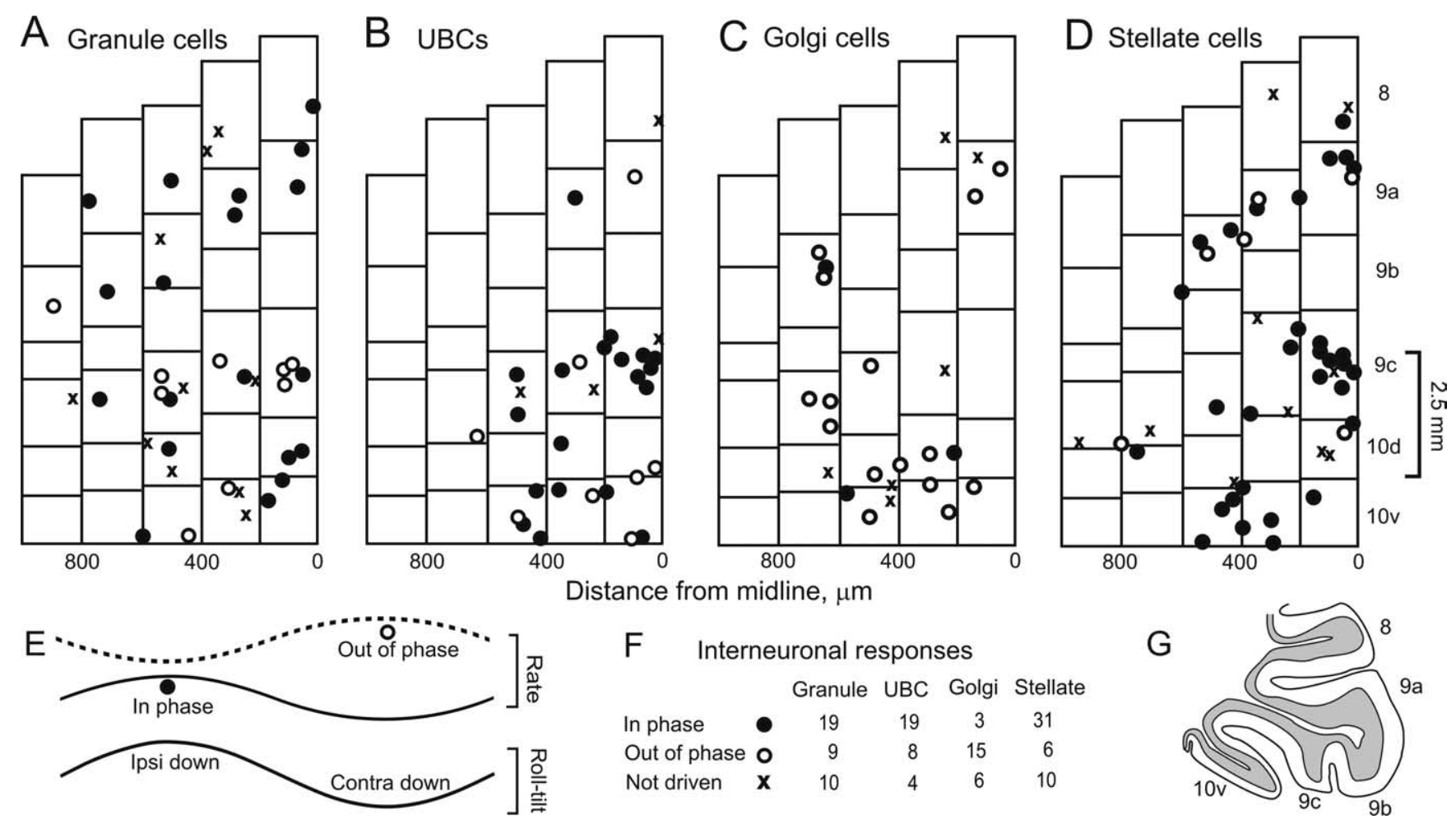

F Interneuronal responses

$\begin{array}{lrrrrr} & & \text { Granule } & \text { UBC } & \text { Golgi } & \text { Stellate } \\ \text { In phase } & - & 19 & 19 & 3 & 31 \\ \text { Out of phase } & \mathbf{0} & 9 & 8 & 15 & 6 \\ \text { Not driven } & \mathbf{X} & 10 & 4 & 6 & 10\end{array}$

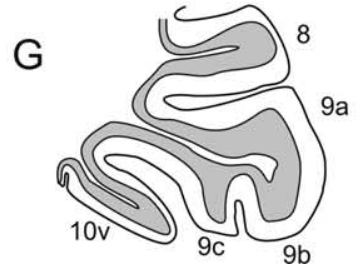

Figure 11. Topography and polarity of interneuronal responses to roll tilt about longitudinal axis. The location of each neurobiotin-labeled interneuron is indicated on a two-dimensional map. $A$, Granule cells. $\boldsymbol{B}$, Unipolar brush cells. C, Golgi cells. D, Stellate cells. The polarity of interneuronal responses to ipsilateral roll tilt about the longitudinal axis is classified as "in phase" (filled circles) or "out of phase" (open circles). Unresponsive cells are indicated by X. $\boldsymbol{F}$, Table summarizes responses for all labeled interneurons. $\boldsymbol{G}$, Sagittal section through the uvula-nodulus shows its correspondence with the two-dimensional representations in $\boldsymbol{A}-\boldsymbol{D}$.

parallel fibers that course through as many as 500 Purkinje cells (Brand et al., 1976; Harvey and Napper, 1991). In contrast, the width of a sagittal vestibular zone in the mouse nodulus is $\sim 400 \mu \mathrm{m}$ (Yakhnitsa and Barmack, 2006), wide enough to include only $\sim 20$ Purkinje cells.

Given this mossy fiber-granule cell circuitry, it is likely that every nodular Purkinje cell receives pan-directional vestibular signals mediated by parallel fibers from most, if not all vestibular endorgans. In contrast, climbing fibers impose a single dimensional input, represented in $400 \mu \mathrm{m}$ wide sagittal zones. The vestibular specificity represented in the discharge of SSs likely can be attributed to cerebellar interneurons driven directly or indirectly by climbing fibers.

\section{Excitatory influence of UBCs on granule cells}

The discharge of UBCs reflects an input mainly from vestibular primary afferent mossy fibers (Rossi et al., 1995; Diño et al., 2000, 2001). UBCs amplify vestibular primary afferent signals and evoke synaptic feedforward excitation of neighboring granule cells. In a heterogeneous population of mossy fibers, feedforward excitation by UBCs confers a higher synaptic weighting to those mossy fibers that are driven by vestibular stimulation. Possibly the high-frequency bursts of granule cells, reflect the influence of UBCs (Hensbroek et al., 2006) (Fig. 5B). Alternatively, these bursts could reflect a rebound from Golgi cell inhibition.

Although the depth of modulation of single mossy fibers faithfully encodes sinusoidal roll tilt, the sensitivity of granule cells to the same stimulus is relatively weak (Figs. 5, 10). Our data do not support the view that signal-to-noise characteris- tics of mossy fibers are enhanced by granule cells (Jörntell and Ekerot, 2006).

\section{Parasagittal organization of Golgi cells}

Contralateral roll tilt increases Golgi cell discharge. Ipsilateral roll tilt decreases it. By discharging in phase with SSs, Golgi cells impose a low-frequency inhibitory feedback on a large and heterogeneous population of granule cells and UBCs. The vestibular modulation of Golgi cell activity could reflect a climbing fiber-dependent signal whose sign is reversed by an inhibitory interneuron, say stellate cells. It could also reflect the same interneuronal activity that modulates SSs. Unlike the limited axonal network of UBCs, the distribution of Golgi cell axon terminals is extensive, enabling a single Golgi cell to influence the activity of thousands of granule cells arrayed within a sagittal zone.

The planar organization of Golgi cell axon terminals may fulfill different functions than the planar organization of Purkinje cell dendrites. Planar dendrites allow Purkinje cells to be packed densely while at the same time receiving a maximal array of synaptic inputs from parallel fibers. The planar organization of Golgi cell axon terminals assures that Golgi cell signals will be restricted to a narrow sagittal array of granule cells (Fig. 8).

The activities of UBCs and Golgi cells may be complementary. UBCs increase the excitatory influence of vestibular primary mossy fiber afferents on granule cells during ipsilateral roll tilt. The efficacy of UBCs is locally restricted to the population of mossy fiber afferents that contact their brush dendrites and the collection of granule cells within range of UBC axonal terminals. Golgi cells increase inhibition of granule cells during contralat- 
eral roll tilt possibly enhancing the dynamic range of granule cell discharge within a sagittal zone. The origin of this Golgi cell discharge is unknown. It may originate from either parallel or climbing fibers (Hámori and Szentágothai, 1966, 1980; Desclin, 1976; Sugihara et al., 1999). Future experiments in which activation by either mossy or climbing fibers is selectively reduced should address this question.

Golgi cells have been juxtacellularly labeled previously (Simpson et al., 2005; Holtzman et al., 2006). In rabbits, the lower mean discharge frequency of Golgi cells combined with a narrow range of ISIs may distinguish Golgi cells from neighboring Purkinje cells and obviate the need for juxtacellular labeling. In mice, the large variability of Golgi cell discharge makes their identification using only physiological criteria problematic.

The activity of Golgi cells in cerebellar crus I and II is reduced by stimulation of both ipsilateral and contralateral trigeminal or forelimb afferents (Holtzman et al., 2006). This contrasts with our observation that Golgi cells consistently respond to contralateral roll tilt. Additional experiments will be required to sort out the effects of Golgi cell discharge on information processing at the mossy fiber-granule cell synapse.

\section{Stellate cells contribute to antiphasic modulation of CSs and SSs}

Stellate and basket cells respond in phase with vestibularly evoked climbing fiber activity. They could inhibit Purkinje cells after a CS and thereby account for the antiphasic discharge of CSs and SSs. Stellate cells release GABA onto $\mathrm{GABA}_{\mathrm{A}} \alpha_{1}$ receptors on the dendrites of Purkinje cells, Golgi cells and stellate cells (Pouzat and Hestrin, 1997). Our present data do not address the question of whether parallel or climbing fibers are more potent in modulating stellate cell activity. Previously we showed that a unilateral labyrinthectomy, which eliminates ipsilateral primary afferent mossy fibers, does not decrease ipsilateral SS modulation. Conversely unilateral inferior olivary microlesions leave vestibular primary afferents intact, but reduce modulation of contralateral CSs and SSs (Barmack and Yakhnitsa, 2003). These findings suggest that the discharge of climbing fibers is critical for modulation of SSs. The present data demonstrate that stellate and basket cells have the correct polarity to account for this inhibitory modulation.

Stellate cells receive a signal that is correlated with climbing fiber discharge (Ohtsuki et al., 2004). The synaptic basis of this signal is currently unknown. Like basket cells, stellate cells receive no somatic synaptic contacts from climbing fibers (Hámori and Szentágothai, 1980). This does not exclude the possibility of axodendritic contacts (Scheibel and Scheibel, 1954). Electrical stimulation of the contralateral inferior olive excites stellate cells with a synaptic delay of 1-3 ms. This variable delay is independent of the amplitude of the extracellularly recorded climbing fiberevoked field potential, implying that the CF-associated response might not be attributable directly to a climbing fiber synapse on stellate cells (Jörntell and Ekerot, 2003).

"Spillover" of glutamate from climbing fiber synapses on Purkinje cell dendrites could increase the activity of stellate cells (Szapiro and Barbour, 2007). Alternatively, climbing fibers might influence stellate cells indirectly through a glutamate sensitive excitation of Bergmann glial astrocytes (Brockhaus and Deitmer, 2002) and astrocytic progenitor $\mathrm{NG}^{2+}$ cells (Lin et al., 2005).

\section{Overview}

Six cerebellar interneurons potentially contribute to the modulation of SSs. Two of these interneurons, granule cells and UBCs are excitatory. Their activity is modulated by vestibular roll tilt and out of phase with respect to vestibularly evoked SS modulation. The discharge of one class of inhibitory interneuron, Golgi cells, is modulated in phase with SSs and cannot account for decreased discharge of SSs after vestibularly evoked CSs. The discharge of two inhibitory interneurons (basket and stellate cells) is modulated out of phase with SSs. These two inhibitory interneurons have the correct phase to account for climbing fiber-evoked antiphasic modulation of SSs. A fourth inhibitory interneuron, the Lugaro cell, was not well represented in our recordings. Climbing fibers, acting directly or indirectly through basket and stellate cells may impose specific vestibular output signals on SSs within well defined parasagittal zones. This view can be tested directly in future experiments in which the discharge of Purkinje cell SSs is examined after the unilateral disruption of either climbing fiber or mossy fiber pathways.

\section{References}

Alley K, Baker R, Simpson JI (1975) Afferents to the vestibulo-cerebellum and the origin of the visual climbing fibers in the rabbit. Brain Res 98:582-589.

Andersen P, Eccles JC, Voorhoeve PE (1964) Postsynaptic inhibition of cerebellar Purkinje cells. J Neurophysiol 27:1138-1153.

Armstrong DM, Edgley SA (1988) Discharges of interpositus and Purkinje cells of the cat cerebellum during locomotion under different conditions. J Physiol (Lond) 400:425-445.

Armstrong DM, Rawson JA (1979) Activity patterns of cerebellar cortical neurones and climbing fibre afferents in the awake cat. J Physiol (Lond) 289:425-448.

Barmack NH, Shojaku H (1995) Vestibular and visual signals evoked in the uvula-nodulus of the rabbit cerebellum by natural stimulation. J Neurophysiol 74:2573-2589.

Barmack NH, Yakhnitsa V (2000) Vestibular signals in the parasolitary nucleus. J Neurophysiol 83:3559-3569.

Barmack NH, Yakhnitsa V (2003) Cerebellar climbing fibers modulate simple spikes in cerebellar Purkinje cells. J Neurosci 23:7904-7916.

Barmack NH, Baughman RW, Errico P, Shojaku H (1993a) Vestibular primary afferent projection to the cerebellum of the rabbit. J Comp Neurol 327:521-534.

Barmack NH, Fagerson M, Fredette BJ, Mugnaini E, Shojaku H (1993b) Activity of neurons in the beta nucleus of the inferior olive of the rabbit evoked by natural vestibular stimulation. Exp Brain Res 94:203-215.

Blazquez PM, Hirata Y, Heiney SA, Green AM, Highstein SM (2003) Cerebellar signatures of vestibulo-ocular reflex motor learning. J Neurosci 23:9742-9751.

Bloedel JR, Roberts WJ (1971) Action of climbing fibers in cerebellar cortex of the cat. J Neurophysiol 34:17-31.

Brand S, Dahl AL, Mugnaini E (1976) The length of parallel fibers in the cat cerebellar cortex. An experimental light and electron microscopic study. Exp Brain Res 26:39-58.

Brockhaus J, Deitmer JW (2002) Long-lasting modulation of synaptic input to Purkinje neurons by Bergmann glia stimulation in rat brain slices. J Physiol (Lond) 545:581-593.

Brodal A, Brodal P (1985) Observations on the secondary vestibulocerebellar projections in the macaque monkey. Exp Brain Res 58:62-74.

Brodal A, Hoivik B (1964) Site and mode of termination of primary vestibulocerebellar fibres in the cat. Arch Ital Biol 102:1-21.

Brodal A, Torvik A (1957) The origin of secondary vestibulo-cerebellar fibers in cats; an experimental anatomical study. Arch Psychiatr Nervenkr Z Gesamte Neurol Psychiatr 195:550-567.

Cajal SR (1911) Histologie du système nerveux de l'homme et des vertebrés. Paris: Maloine.

Carleton SC, Carpenter MB (1984) Distribution of primary vestibular fibers in the brainstem and cerebellum of the monkey. Brain Res 294:281-298

Carpenter MB, Stein BM, Peter P (1972) Primary vestibulocerebellar fibers in the monkey: distribution of fibers arising from distinctive cell groups of the vestibular ganglia. Am J Anat 135:221-250. 
Desclin JC (1976) Early terminal degeneration of cerebellar climbing fibers after destruction of the inferior olive in the rat. Synaptic relationships in the molecular layer. Anat Embryol (Berl) 149:87-112.

Diño MR, Schuerger RJ, Liu YB, Slater NT, Mugnaini E (2000) Unipolar brush cell: a potential feedforward excitatory interneuron of the cerebellum. Neuroscience 98:625-636.

Diño MR, Perachio AA, Mugnaini E (2001) Cerebellar unipolar brush cells are targets of primary vestibular afferents: an experimental study in the gerbil. Exp Brain Res 140:162-170.

Dugué GP, Dumoulin A, Triller A, Dieudonné S (2005) Target-dependent use of coreleased inhibitory transmitters at central synapses. J Neurosci 25:6490-6498.

Ebner TJ, Bloedel JR (1981) Role of climbing fiber afferent input in determining responsiveness of Purkinje cells to mossy fiber inputs. J Neurophysiol 45:962-971.

Eccles JC, Llinás R, Sasaki K (1965) The inhibitory interneurones within the cerebellar cortex. Exp Brain Res 1:1-16.

Eccles JC, Llinás R, Sasaki K (1966) The mossy fibre-granule cell relay of the cerebellum and its inhibitory control by Golgi cells. Exp Brain Res $1: 82-101$.

Epema AH, Gerrits NM, Voogd J (1990) Secondary vestibulocerebellar projections to the flocculus and uvulo-nodular lobule of the rabbit: a study using HRP and double fluorescent tracer techniques. Exp Brain Res 80:72-82.

Fox CA, Hillman DE, Siegesmund KA, Dutta CR (1967) The primate cerebellar cortex: a Golgi and electron microscopic study. In: Progress in Brain Res, Vol. XXV, The cerebellum (Fox CA, Snider RS, eds), pp 174-225. New York: Elsevier.

Fukushima K, Fukushima J, Kaneko CR, Fuchs AF (1999) Vertical Purkinje cells of the monkey floccular lobe: simple-spike activity during pursuit and passive whole body rotation. J Neurophysiol 82:787-803.

Fushiki H, Barmack NH (1997) Topography and reciprocal activity of cerebellar Purkinje cells in the uvula-nodulus modulated by vestibular stimulation. J Neurophysiol 78:3083-3094.

Gerrits NM, Epema AH, Van Linge A, Dalm E (1989) The primary vestibulocerebellar projection in the rabbit: absence of primary afferents in the flocculus. Neurosci Lett 105:27-33.

Granit R, Phillips CG (1956) Excitatory and inhibitory processes acting upon individual Purkinje cells of the cerebellum in cats. J Physiol (Lond) 133:520-547.

Hámori J, Szentágothai J (1966) Participation of Golgi neuron processes in the cerebellar glomeruli: an electron microscope study. Exp Brain Res 2:35-48.

Hámori J, Szentágothai J (1980) Lack of evidence of synaptic contacts by climbing fibre collaterals to basket and stellate cells in developing rat cerebellar cortex. Brain Res 186:454-457.

Harvey RJ, Napper RM (1991) Quantitative studies on the mammalian cerebellum. Prog Neurobiol 36:437-463.

Hensbroek R, Van Beugen BJ, Ruigrok TJ, Simpson JI (2006) Spike modulation of unipolar brush cells and granule cells in the cerebellum of the awake rabbit. Soc Neurosci Abstr 32:740.2.

Holtzman T, Rajapaksa T, Mostofi A, Edgley SA (2006) Different responses of rat cerebellar Purkinje cells and Golgi cells evoked by widespread convergent sensory inputs. J Physiol (Lond) 574:491-507.

Ito M (1984) The cerebellum and neural control. New York: Raven.

Jörntell H, Ekerot CF (2003) Receptive field plasticity profoundly alters the cutaneous parallel fiber synaptic input to cerebellar interneurons in vivo. J Neurosci 23:9620-9631.

Jörntell H, Ekerot CF (2006) Properties of somatosensory synaptic integration in cerebellar granule cells in vivo. J Neurosci 26:11786-11797.

Kano M, Kano M-S, Maekawa K (1991) Simple spike modulation of Purkinje cells in the cerebellar nodulus of the pigmented rabbit to optokinetic stimulation. Neurosci Lett 128:101-104.

Kevetter GA, Perachio A (1986) Distribution of vestibular afferents that innervate the sacculus and posterior canal in the gerbil. J Comp Neurol 254:410-424.

Kobayashi Y, Kawano K, Takemura A, Inoue Y, Kitama T, Gomi H, Kawato M (1998) Temporal firing patterns of Purkinje cells in the cerebellar ventral paraflocculus during ocular following responses in monkeys II. Complex spikes. J Neurophysiol 80:832-848.

Korte GE (1979) The brainstem projection of the vestibular nerve in the cat. J Comp Neurol 184:279-292.
Kotchabhakdi N, Walberg F (1978) Cerebellar afferent projections from the vestibular nuclei in the cat: an experimental study with the method of retrograde axonal transport of horseradish peroxidase. Exp Brain Res 31:591-604.

Lin SC, Huck JH, Roberts JD, Macklin WB, Somogyi P, Bergles DE (2005) Climbing fiber innervation of NG2-expressing glia in the mammalian cerebellum. Neuron 46:773-785.

Lisberger SG, Pavelko TA, Bronte-Stewart HM, Stone LS (1994) Neural basis for motor learning in the vestibuloocular reflex of primates. II. Changes in the responses of horizontal gaze velocity Purkinje cells in the cerebellar flocculus and ventral paraflocculus. J Neurophysiol 72:954-973.

Maklad A, Fritzsch B (2003) Partial segregation of posterior crista and saccular fibers to the nodulus and uvula of the cerebellum in mice, and its development. Dev Brain Res 140:223-236.

McDevitt CJ, Ebner TJ, Bloedel JR (1982) The changes in Purkinje cell simple spike activity following spontaneous climbing fiber inputs. Brain Res 237:484-491.

Monsivais P, Clark BA, Roth A, Häusser M (2005) Determinants of action potential propagation in cerebellar Purkinje cell axons. J Neurosci 25:464-472.

Mugnaini E (1983) The length of cerebellar parallel fibers in chicken and Rhesus monkey. J Comp Neurol 220:7-15.

Mugnaini E, Floris A (1994) The unipolar brush cell: a neglected neuron of the mammalian cerebellar cortex. J Comp Neurol 339:174-180.

Nagao S (1989) Role of cerebellar flocculus in adaptive interaction between optokinetic eye movement response and vestibulo-ocular reflex in pigmented rabbits. Exp Brain Res 77:541-551.

Newlands SD, Purcell IM, Kevetter GA, Perachio AA (2002) Central projections of the utricular nerve in the gerbil. J Comp Neurol 452:11-23.

Nunzi MG, Birnstiel S, Bhattacharyya BJ, Slater NT, Mugnaini E (2001) Unipolar brush cells form a glutamatergic projection system within the mouse cerebellar cortex. J Comp Neurol 434:329-341.

Ohtsuki G, Kawaguchi SY, Mishina M, Hirano T (2004) Enhanced inhibitory synaptic transmission in the cerebellar molecular layer of the GluRdelta2 knock-out mouse. J Neurosci 24:10900-10907.

Pichitpornchai C, Rawson JA, Rees S (1994) Morphology of parallel fibers in the cerebellar cortex of the rat: an experimental light and electronmicroscopic study with biocytin. J Comp Neurol 342:206-220.

Pinault D (1996) A novel single-cell staining procedure performed in vivo under electrophysiological control: morpho-functional features of juxtacellularly labeled thalamic cells and other central neurons with biocytin or Neurobiotin. J Neurosci Methods 65:113-136.

Pouzat C, Hestrin S (1997) Developmental regulation of basket/stellate cell $\rightarrow$ Purkinje cell synapses in the cerebellum. J Neurosci 17:9104-9112.

Purcell IM, Perachio AA (2001) Peripheral patterns of terminal innervation of vestibular primary afferent neurons projecting to the vestibulocerebellum in the gerbil. J Comp Neurol 433:48-61.

Rossi DJ, Alford S, Mugnaini E, Slater NT (1995) Properties of transmission at a giant glutamatergic synapse in cerebellum: the mossy fiber-unipolar brush cell synapse. J Neurophysiol 74:24-42.

Scheibel ME, Scheibel AB (1954) Observations on the intracortical relations of the climbing fibers of the cerebellum; a Golgi study. J Comp Neurol 101:733-763.

Schiffmann SN, Cheron G, Lohof A, D’Alcantara P, Meyer M, Parmentier M, Schurmans S (1999) Impaired motor coordination and Purkinje cell excitability in mice lacking calretinin. Proc Natl Acad Sci USA 96:5257-5262.

Schonewille M, Khosrovani S, Winkelman BH, Hoebeek FE, De Jeu MT, Larsen IM, Van der BJ, Schmolesky MT, Frens MA, De Zeeuw CI (2006) Purkinje cells in awake behaving animals operate at the upstate membrane potential. Nat Neurosci 9:459-461.

Schor RH, Miller AD, Tomko DL (1984) Responses to head tilt in cat central vestibular neurons. I. Direction of maximum sensitivity. J Neurophysiol 51:136-146.

Simpson JI, Hulscher HC, Sabel-Goedknegt E, Ruigrok TJ (2005) Between in and out: linking morphology and physiology of cerebellar cortical interneurons. Prog Brain Res 148:329-340.

Sugihara I, Wu H, Shinoda Y (1999) Morphology of single olivocerebellar 
axons labeled with biotinylated dextran amine in the rat. J Comp Neurol 414:131-148.

Szapiro G, Barbour B (2007) Multiple climbing fibers signal to molecular layer interneurons exclusively via glutamate spillover. Nat Neurosci 10:735-742.

Thach WT (1970) Discharge of cerebellar neurons related to two maintained postures and two prompt movements. II. Purkinje cell output and input. J Neurophysiol 33:537-547.

Thunnissen IE, Epema AH, Gerrits NM (1989) Secondary vestibulocerebellar mossy fiber projection to the caudal vermis in the rabbit. J Comp Neurol 290:262-277.

Vos BP, Volny-Luraghi A, De Schutter E (1999) Cerebellar Golgi cells in the rat: receptive fields and timing of responses to facial stimulation. Eur J Neurosci 11:2621-2634.
Winkelman B, Frens M (2006) Motor coding in floccular climbing fibers. J Neurophysiol 95:2342-2351.

Wu HS, Sugihara I, Shinoda Y (1999) Projection patterns of single mossy fibers originating from the lateral reticular nucleus in the rat cerebellar cortex and nuclei. J Comp Neurol 411:97-118.

Yakhnitsa V, Barmack NH (2006) Antiphasic Purkinje cell responses in mouse uvula-nodulus are sensitive to static roll tilt and topographically organized. Neuroscience 143:615-626.

Yamamoto M (1979) Topographical representation in rabbit cerebellar flocculus for various afferent inputs from the brainstem investigated by means of retrograde axonal transport of horseradish peroxidase. Neurosci Lett 12:29-34.

Zar JH (1984) Biostatistical analysis. Englewood Cliffs, NJ: PrenticeHall. 